\title{
Surface energy balance fluxes in a suburban of Beijing: energy partitioning variability
}

Junxia Dou ${ }^{1}$, Sue Grimmond ${ }^{2}$, Shiguang Miao ${ }^{1}$, Bei Huang ${ }^{3}$, Huimin Lei $^{3}$, Mingshui

Liao $^{4}$

$5 \quad{ }^{1}$ Institute of Urban Meteorology, China Meteorological Administration, Beijing 100089, China

${ }^{2}$ Department of Meteorology, University of Reading, Reading, RG6 6ET, UK

${ }^{3}$ Department of Hydraulic Engineering, Tsinghua University, Beijing 100084, China

${ }^{4}$ Miyun Meteorological station, Beijing Meteorological Bureau, Beijing 101599, China

Correspondence to: Junxia Dou (jxdou@ium.cn)

10 Abstract. Measurements of radiative and turbulent heat fluxes for 16 months in suburban Miyun with a mix of buildings and agriculture allows the changing role of these fluxes to be assessed. Daytime turbulent latent heat fluxes $\left(Q_{E}\right)$ are largest in summer and smaller in winter, consistent with the net all wave radiation $\left(Q^{*}\right)$. Whereas, the daytime sensible heat flux $\left(Q_{H}\right)$ is greatest in spring but smallest in summer, rather than winter as commonly observed in suburban areas. The results have larger seasonal between: $0.15-0.57$ for $Q_{H} / Q^{*}$ (mean summer=0.16, winter=0.46); 0.06-0.56 for $Q_{E} / Q^{*}$ (mean summer=0.52, winter=0.10), and 0.26-7.40 for $Q_{H} / Q_{E}$ (mean summer=0.32; winter=4.60). Compared to the literature for suburban areas, these are amongst the lowest and highest values. Results indicate that precipitation, irrigation, crop/vegetation growth activity and land use/cover all play critical roles in the energy partitioning. These results will help to enhance our understanding of surface-atmosphere energy exchanges over cities, and are critical to improving and evaluating urban canopy models needed to support integrated urban services, that include urban planning to mitigate the adverse effects of urban climate change.

\section{Introduction}

In the atmospheric boundary layer, turbulent flows are fundamental to mass and energy transport, so are regarded as basic part of comprehensive observation studies of the urban boundary layer, such as the UBL/CLU-ESCOMPTE project in Marseille, France (Mestayer et al., 2005), the BUBBLE project in Basel, Switzerland (Rotach et al., 2005), and the SURF experiment in Beijing, China (Liang et al., 2018). The eddy covariance method (EC) allows direct measurement of heat and water vapor exchange between 
30 the surface and the atmosphere, and is considered the best method to obtain turbulent fluxes (Baldocchi, 2003). These have provided information about surface energy balance exchanges (Oke et al., 2017), helped development of parameterizations (Grimmond and Oke, 1999b, 2002; Järvi et al., 2019), and evaluation and application of land surface models (Grimmond et al., 2010; Järvi et al., 2011; Järvi et al., 2014; Karsisto et al., 2015; Ward et al., 2016; Liu et al., 2017; Kim et al., 2019) and remote sensing products (Kim and Kwon, 2019). In recent years, these have been widely undertaken in cities around the world.

The EC method sites cover most of the Local Climate Zones (LCZs) (Stewart and Oke, 2012), from compact high-rise, midrise and low-rise (LCZ1-LCZ3), to open high-rise, midrise and low-rise (LCZ4LCZ6), and large low-rise (LCZ8) (Oke et al., 2017). The land use of these sites are mainly residential and commercial areas (Vesala et al., 2008; Bergeron and Strachan, 2012; Ao et al., 2016a; Roth et al., 2017; Hong et al., 2019), as well as institutions and universities (Guo et al., 2016), industrial areas (Grimmond and Oke, 1999b; Offerle et al., 2006b). These have located in different region settings, including desert (Frey et al., 2011) but with airports (Cleugh and Oke, 1986; Offerle et al., 2006b) used for context. The impervious (e.g. buildings, parking lots, roads) to pervious (e.g. trees, grass) land cover in the EC source area span a large range from $22 \% / 78 \%$ in Łódz', Poland (Offerle et al., 2006b) to 100\%/0 in Basel, Switzerland (Christen and Vogt, 2004). The earliest observations were generally for short periods (few days to several months) (e.g. Grimmond and Oke, 1995; Spronken-Smith, 2002). With more observational experience and recognition of the benefits of longer periods, funders have supported longer measurement periods. Measurements that cover a season, a year, or even many years (e.g. Christen and Vogt, 2004; Moriwaki and Kanda, 2004; Offerle et al., 2006a, b; Vesala et al., 2008; Ward et al., 2013; Kotthaus and Grimmond, 2014a; Ao et al., 2016a; Roth et al., 2017; Tomoya and Masahito, 2017) provide many new insights.

In Beijing, observations been taken in a densely built-up commercial and residential area (Liu et al., 2012; Miao et al., 2012, Wang et al., 2015), an open midrise residential - large agricultural area (Dou et al., 2019), and a rural area (Wang et al., 2015). These include observations for 1-year at the urban and rural sites, both individually and concurrently. However, there is still a need to investigate seasonal variations in the suburban area, to understand the key factors impacting the surface energy balance at different timescales as to-date only summer-time observations have been analyzed (Dou et al., 2019). 
In this study, daily, monthly, and seasonal variations in surface energy fluxes for a suburban site 60 (Miyun) in the Beijing are analyzed using 16-months of observations. We focus on the role of site characteristics and environmental factors impacts on energy partitioning.

\section{Methods}

\subsection{Site description}

Miyun, located about $80 \mathrm{~km}$ northeast of the center of Beijing city (Tian'anmen Square) (Fig. 1a), has an area of $50 \mathrm{~km}^{2}$ and population of $\sim 500,000$ (in 2019) (Beijing Miyun Statistical Yearbook, 2020). The Miyun Meteorological Station (MY; $116^{\circ} 51^{\prime} 51^{\prime \prime} \mathrm{E}, 40^{\circ} 22^{\prime} 39^{\prime \prime} \mathrm{N}$ ), on the southeast edge of Miyun city is in a transition zone between the city and the countryside (Fig. 1b, c). Using the Stewart and Oke (2012) Local Climate Zone classification, the site is LCZ5 - 'Regular Housing (treed/open)' class.

Within a $1 \mathrm{~km}$ radius of the Miyun instrumented tower, the surface is $69.6 \%$ impervious (buildings, roads, and parking lots) and 30.3\% vegetation (wheat/maize rotation farmland, orchard, vegetable plots, grass lawn) based on analysis of a GF-2 High-resolution image (CCRSDA, 2016) with a spatial resolution of $1 \mathrm{~m}$ (Fig. 1c). To the east and southeast of the tower, there is farmland. The mainly residential 6-storey $(\sim 18 \mathrm{~m})$ buildings are at varying distances (west: from $170 \mathrm{~m}$; northwest $>200 \mathrm{~m}$; north: $>70 \mathrm{~m}$ ) of the tower. Other buildings include the farmer's 1-2 storey house (3.5-7.3 m) which is about $300 \mathrm{~m}$ northeast of the tower. Since 2016 to the southwest (500-1000 m), newer taller (18-34 m) residential buildings have been built. To the south (150-500 m away) are office (height: $8-50 \mathrm{~m}$ ) and light commercial buildings (small shops, $8-12 \mathrm{~m}$ ). Southwest of the tower, there is a roundabout that connects the two main roads in the study area: east-west Jingmi Road (170 m to south) and north-south Tanxi Road (420 m to west). 

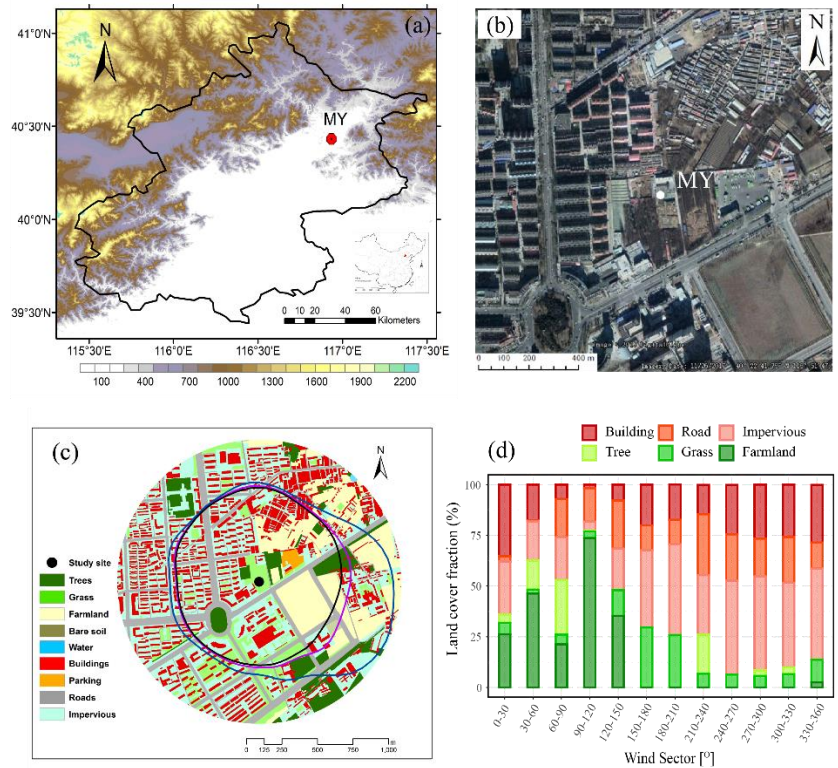

Figure 1: Study area (a) Beijing topography with Miyun (MY) (inset; location in China, red dot); (b) aerial view around MY flux tower (C Google Earth 2017); (c) land cover within $1 \mathrm{~km}$ radius around MY flux tower (black dot) eddy covariance ( $90 \%$ source area) for daytime $\left(K_{\downarrow}>5 \mathrm{~W} \mathrm{~m}^{-2}\right.$, black line), night (blue) and daily average (pink), and (d) daily mean land cover derived from GF-2 High-resolution image (CCRSDA, 2016) for $30^{\circ}$ wind sectors of the 90\% source area (shown in c).

\subsection{Instruments and data processing}

Both the eddy covariance (EC) system and radiometer are mounted $36 \mathrm{~m}$ above ground level (agl) on a 38-m triangular lattice tower, with the EC system pointing into the prevailing wind direction (east) and the radiometer south to avoid shadows. The EC system's three-dimensional sonic anemometerthermometer (CSAT3, Campbell Scientific Inc., USA) measures vertical, horizontal, and lateral wind velocity and virtual temperature; and the open-path infrared gas analyzer (LI-7500, LI-COR, Inc., USA) measures water vapor and carbon dioxide molar densities. The $10 \mathrm{~Hz}$ data are logged on a CR3000 datalogger (Campbell Scientific Inc, USA). The $30 \mathrm{~min}$ turbulent sensible and latent heat fluxes are obtained using the EddyPro Advanced (v6.1.0 beta, LI-COR) software with standard correction procedures (Moncrieff et al., 1997) applied to ensure data quality (e.g., de-spiking raw data, tilt correction, time-lag 
analysis (Table 1). Data are excluded during rain and, $2 \mathrm{~h}$ after rain, or if low friction velocity $(<0.1 \mathrm{~m}$ s-1) occurred (Table 1). Wind direction data are corrected for changes in magnetic declination as EC sensor install based on magnetic north.

The radiation fluxes, measured with a CNR4 radiometer (Kipp \& Zonen, Netherlands), are 1-min samples by the CR3000 data-logger, from which the 30-min means are calculated. The incoming and outgoing longwave $\left(L_{\downarrow}\right.$ and $\left.L_{\uparrow}\right)$ and shortwave $\left(K_{\downarrow}\right.$ and $\left.K_{\uparrow}\right)$ radiation and net all-wave radiation $\left(Q^{*}\right)$ data are restricted to physically reasonable thresholds, with nocturnal shortwave radiation forced to $0 \mathrm{~W} \mathrm{~m}^{-2}$ (Michel et al., 2008).

During the 16 month period analyzed (September 2012-December 2013), after instrument failures (31 October 2012, 30 November to 1 December 2012, 14 January to 18 February 2013 and 18 June 2013) and other quality control, $91.6 \%(\mathrm{~N}=21416,30$ min periods $)$ of the radiation, $78.9 \%(\mathrm{~N}=18453)$ of sensible heat $\left(Q_{H}\right)$ and $77.3 \%(\mathrm{~N}=18059)$ of the latent heat fluxes $\left(Q_{E}\right)$ data are available.

Additional observations analyzed are from an automatic weather station located $30 \mathrm{~m}$ from the EC tower, variables include: air temperature (HMP155, Vaisala, Finland) measured at $1.5 \mathrm{~m}$ agl, precipitation from a tipping bucket rain gauge (SL3-1, Shanghai Meteorological Instrument Factory, China) mounted at $0.7 \mathrm{~m} \mathrm{agl}$ (April to October), and from a weighing bucket rain gauge (DSC1, Aerospace Newsky Technology, China) mounted at $1.5 \mathrm{~m} \mathrm{agl} \mathrm{(November} \mathrm{to} \mathrm{March);} \mathrm{wind} \mathrm{speed} \mathrm{and}$ direction (ZQZ-TF, Aerospace Newsky Technology, China) measured at $10 \mathrm{~m}$ agl, and soil temperature (ZQZ-TW, Aerospace Newsky Technology, China) measured at 0, 0.05, 0.10, 0.20, 0.40, 0.80, 1.6 and $3.2 \mathrm{~m}$ below ground. These data are sampled at $1 \mathrm{~s}$, except for wind speed and direction $(0.25 \mathrm{~s})$, and averaged to $1 \mathrm{~min}$ (WUSH-BH, Aerospace Newsky Technology, China). Hourly means (or accumulated totals for precipitation) are used here. Quality control checks include: plausible range, internal consistency, temporal and spatial consistency, and other standard China Meteorological Administration network checks (Ren et al., 2015).

Soil moisture content is measured from gravimetric samples collected with a straight-shank drill with a scale. Measurements are taken on the 8th, 18th and 28th of each month within the $300 \mathrm{~m}$ of the site between 8th March and 28th November each year at five equally spaced depths $(0.1 \mathrm{~m}$ interval to 


\subsection{Meteorological conditions during the study period}

The study period (1 September 2012 to 31 December 2013) is compared to Normal (1991-2020) MY weather station data. The range in mean 2-m air temperature is between $-13.3(23 \mathrm{Dec} 2012)$ and $29.4{ }^{\circ} \mathrm{C}$ (17 Aug 2013) at the daily scale, and between -7.0 (Jan 2013) to $26.1^{\circ} \mathrm{C}$ (July 2013) for monthly scale

135 (Fig. 2a). There are only small deviations from Normal in the monthly mean air temperatures, with biggest differences (December 2012, April 2013) both $3.1^{\circ} \mathrm{C}$ cooler than Normal.

The study period precipitation differed significantly from Normal conditions in the region (Fig. 2b). The 2012 was extremely wet, especially on a monthly basis with November $(77.4 \mathrm{~mm})$ and December $(10.6 \mathrm{~mm})$ about $580 \%$ and $400 \%$ greater than the Normal (13.4 mm, November; $2.7 \mathrm{~mm}$, December), respectively. In contrast, most of 2013 had below average rainfall, except for June which was wetter (186.7 mm, 223\% of the Normal). Notably, dry spells occurred in May, November, and December 2013. Only $0.7 \mathrm{~mm}$ (1.6\% of Normal) rainfall fell in May and there was no rain in November and December 2013 at all.

Easterly winds $\left(30-120^{\circ}\right)$ prevailed in MY every season in the night and for the whole day, with a $62 \%$ in winter (Fig. 2c-j). During the daytime, wind also comes from southwest direction $\left(180-270^{\circ}\right)$ as a result of mountain-valley breeze, despite southwest wind differed in existence hours among seasons (Fig. 4g-j). In addition, the strongest winds (wind speed $>5 \mathrm{~m} \mathrm{~s}^{-1}$ ) mainly came from the northeast (30$60^{\circ}$ ), with a higher relative frequency in spring and winter (Fig. 2c-f). 


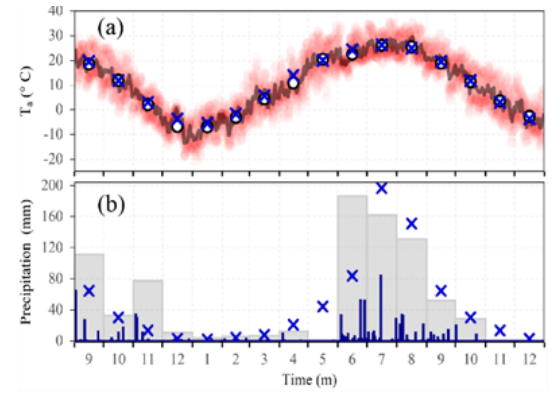

(c)

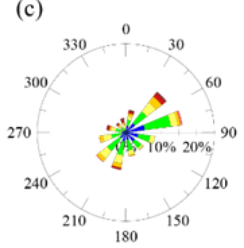

(d)

$$
330
$$

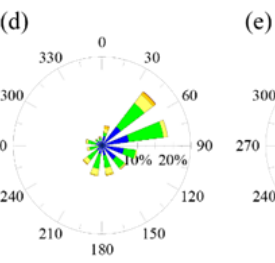

(e)
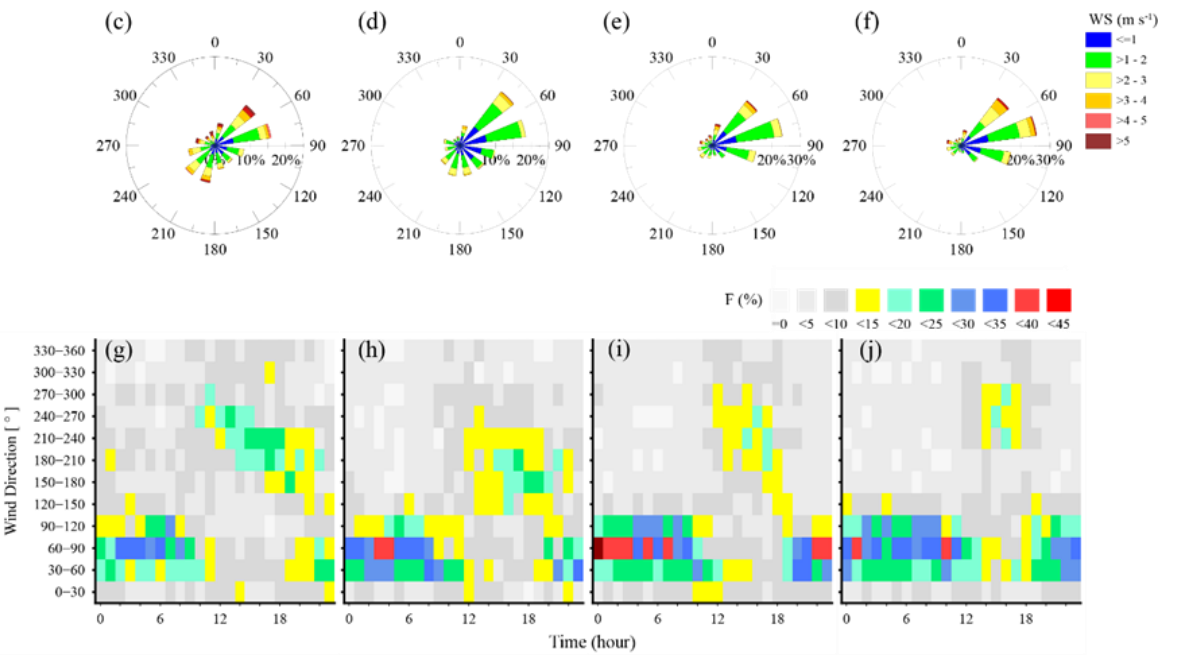

Figure 2: Monthly normal (1991-2020, blue crosses) and automated weather station data (September 2012 to December 2013): (a) $2 \mathrm{~m}$ air temperature (Ta) as $1 \mathrm{~h}$ (dots), daily (solid line), monthly averages (white circles); (b) daily (blue), monthly (grey) precipitation; wind roses $\left(30^{\circ}\right.$ bins, $1 \mathrm{~h}$ data) stratified by wind speed frequency for (c) spring (MAM), (d) summer (JJA), (e) autumn (SON), (f) winter (DJF); frequency distribution of wind direction $\left(30^{\circ}\right.$, 1 h data) by time of day for (g) MAM, (h) JJA, (i) SON, and (j) DJF.

\subsection{EC Footprint analyses}

To calculate the turbulent fluxes source areas for each 30-min period we use the Kljun et al. (2004) EC footprint model. The roughness length for momentum $\left(z_{0}\right)$ and zero plane displacement height $\left(z_{d}\right)$ input parameters are based on the height of roughness elements within a $1 \mathrm{~km}$ radius of the EC tower. The buildings vary from 3.0 to $50.4 \mathrm{~m}$, with shorter farmers' houses (northeast) $3.5-7.3 \mathrm{~m}$ and residential buildings (west to northwest) 16.0-18.5 m, than the buildings to the south, southwest and north (mostly > $20 \mathrm{~m})$. The tallest building $(50.4 \mathrm{~m})$ is directly south of the tower. The mean weighted by plan area fraction building height $\left(z_{h}\right)$ is $13.1 \mathrm{~m}$. The trees are along roadsides, within roundabout median strip, 
public gardens and orchards (Fig. 1c). The average tree height is $8.5 \mathrm{~m}$ (trees $>1.5 \mathrm{~m}$ ), varying between are a relatively consistent 7.2 to $9.3 \mathrm{~m}$ (average $=8.6 \mathrm{~m}$ ). The mature wheat (June) is $1.1 \mathrm{~m}$ and maize (September) is $2.7 \mathrm{~m}$. Using a rule of thumb (Grimmond and Oke, 1999a) with a mean building height of $13.1 \mathrm{~m}, z_{0}$ is estimated to be $1.3 \mathrm{~m}$ and $z_{d}$ is $9.2 \mathrm{~m}$. Whereas using Kanda et al. (2013) for $36-10$ degree sectors, give values between 0 and $3.26 \mathrm{~m}\left(z_{0}\right)$, and from 0 to $36.4 \mathrm{~m}\left(z_{d}\right)$; and anemometric estimates are $2.9 \mathrm{~m}$ and $4.1 \mathrm{~m}$ (Dou et al., 2019), respectively. Given that prevailing wind is from the east $\left(30-150^{\circ}\right)$ where vegetation fraction $\left(\lambda_{v}\right)$ occupies $60 \%$ of the plan area $(\leq 1 \mathrm{~km}$ radius of EC tower), the anemometric values are used. By using the iterative method suggested by Kent et al. (2017), the impact of these initial values on the probable turbulent flux source dimensions should become insignificant.

The atmospheric stability parameter $\left(\zeta=\left(\mathrm{z}-z_{d}\right) / \mathrm{L}\right)$ is a function of Obukhov length $(\mathrm{L})$ obtained from the EC observations, the sensor height $(\mathrm{z})$ and $z_{d}$. Here the variation of turbulence is classified into unstable as $\zeta<-0.1$, neutral $|\zeta| \leq 0.1$ and stable conditions $\zeta>0.1$. During the observation period $(\mathrm{N}=17142$, 30 min periods), the stability is predominately unstable (40.9\%) and stable (42.4\%), with neutral conditions for $16.7 \%$ of the time. but split into day $\left(K_{\downarrow}>5 \mathrm{~W} \mathrm{~m}^{-2}\right)$ and night. The median $90 \%$ source area extends to $582-677 \mathrm{~m}$ (by direction) during the daytime and 596-908 $\mathrm{m}$ at night (Fig. 1c), which corresponds to a daily median of 559-676 $\mathrm{m}$. Within these source areas, the land use and land cover vary by sector from being more highly vegetated $\left(30-150^{\circ}\right)$ to more built-up $\left(210-360^{\circ}\right)$ (Fig. 1d).

\subsection{Anthropogenic heat flux}

The LQF version (Lindberg et al., 2018; Gabey et al., 2019) of the large-scale urban consumption of energy model (LUCY) (Allen et al., 2011; Lindberg et al., 2013) is used to calculate anthropogenic heat flux $\left(Q_{F}\right)$. The temperature response coefficients are calculated for MY using local air temperature and electricity consumption, vehicle and population data (Appendix A). 


\subsection{Storage heat flux}

Given the difficultly of measuring the storage heat flux $\left(\Delta Q_{S}\right)$ directly in urban areas (e.g. Offerle et al., 2006b, Roberts et al., 2006), we uses two methods to estimate it:

(1) Objective Hysteresis Model $\Delta Q_{S_{\text {, }} \text { ohm }}$ : see Appendix B for details

(2) Energy balance residual $\Delta Q_{s, r e s}=\left(Q^{*}+Q_{F}\right)-\left(Q_{H}+Q_{E}\right)$ : has the net uncertainties from

observations, for example, the EC fluxes $\left(Q_{H}\right.$ and $\left.Q_{E}\right)$ underestimate by $10-20 \%$ (Wilson et al., 2002;

Foken et al., 2008). Given the prevailing easterly winds $\left(30-150^{\circ}\right)$ (Fig. 2c-j), vegetation accounts for $60 \%$ of the area of which $44 \%$ is cropland (Fig. 1c, d) if $Q_{F}$ is included, the $\Delta Q_{s \text {, res }}$ values should be regarded as the upper limit of heat storage flux (Ward et al., 2013).

\subsection{Data availability and analysis of fluxes}

Analysis is done by season (spring: March-May (MAM), summer: JJA, autumn: SON, and winter: DJF) and by time of day (daytime: $K_{\downarrow}>5 \mathrm{~W} \mathrm{~m}^{-2}$, night: other times). Daytime in spring is from 6:00 to 19:00, summer from 5:30 to 19:30, autumn from 6:30 to 18:00, and winter from 8:00 to 17:30. The data availability for all seasons are summarized in Table 1.

Missing data are not gap-filled. For analyses, that need $24 \mathrm{~h}$ from the mean fluxes are calculated before derived ratios (e.g. Albedo, Bowen ratio). Daytime and daily mean fluxes of net all-wave radiation, sensible heat flux and latent heat flux are estimated based on monthly mean diurnal patterns.

\section{Results and discussion}

\subsection{Surface radiation budget}

At the MY site, all radiation fluxes vary seasonally (Fig. 3). Daytime maxima of incoming short-wave radiation $\left(K_{\downarrow}\right)$ range from about $500 \mathrm{~W} \mathrm{~m}^{-2}$ in winter to $1000 \mathrm{~W} \mathrm{~m}^{-2}$ in summer (Fig. 3a). As expected, daytime maxima of $K_{\downarrow}$ in winter are greater than those for more higher latitude cities (e.g. London, $52^{\circ} \mathrm{N}$ $\sim 200 \mathrm{~W} \mathrm{~m}^{-2}$; Kotthaus and Grimmond, 2014a) and smaller than for lower latitude cities (e.g. Shanghai, $31.19^{\circ} \mathrm{N}, \sim 600 \mathrm{~W} \mathrm{~m}^{-2}$; Ao et al., 2016b), owing to differences in the solar elevation angle. In summer at MY, the daytime maxima of $K_{\downarrow}$ is similar to London (Kotthaus and Grimmond, 2014a) but slightly higher 
reducing $K_{\downarrow}$ exceeding the latitudinal differences. The extremely low $K_{\downarrow}$ values are associated with precipitation, such as recorded in early June 2013 (Fig. 3a).

The outgoing reflected shortwave radiation $\left(K_{\uparrow}\right)$ daytime maxima vary between $65 \mathrm{~W} \mathrm{~m}^{-2}$ (December) and $120 \mathrm{~W} \mathrm{~m}^{-2}$ (July and August). However, some December 2012 and January 2013 exceed $120 \mathrm{~W} \mathrm{~m}^{-2}$ and even $150 \mathrm{~W} \mathrm{~m}^{-2}$ (Fig. 3b) when snow occurred causing albedo becomes increases to 0.6 and then decreases with days since snowfall (Figure Supplementary information S1). The surface heterogeneity, sky conditions, and aerosol concentration affect surface reflectivity at MY. The spring, summer and autumn seasonal variability in midday (10:00-14:00) albedo is between 0.143 and 0.155 in $2012(0.139$ $0.151,2013)$, while in winter in 2012 (2013) it reaches $0.181-0.259(0.183-0.261)$ with the variations in snow cover. Overall, the representative daytime (sunrise to sunset) local-scale albedo is 0.148 , which is slightly larger than the midday (10:00-14:00) value (0.145).

Incoming longwave radiation $\left(L_{\downarrow}\right)$ is primarily influenced by near-surface air temperature and water vapor content (Flerchinger et al., 2009; Kotthaus and Grimmond, 2014a). Thus, the larger $L_{\downarrow}$ values are observed during warm and humid times of the year (i.e. summer - June-August) (Fig. 3c) and smaller values observed in colder winter. The daily maxima of $L_{\downarrow}$ varies between $\sim 320 \mathrm{~W} \mathrm{~m}^{-2}$ (winter) and $\sim 470$ $\mathrm{W} \mathrm{m}^{-2}$ (summer). The monthly mean $L_{\downarrow}$ vary between $420 \mathrm{~W} \mathrm{~m}^{-2}$ (July) and $212 \mathrm{~W} \mathrm{~m}^{-2}$ (January 2013). The latter was the coldest month of the observation period (Sect. 2.3).

Outgoing longwave radiation $\left(L_{\uparrow}\right)$ depends on the surface temperature and emissivity. The former is highly influenced by the total amount of incoming radiative energy. Thus, the larger $L_{\uparrow}$ is observed in summer (Fig. 3d), consistent with the larger $K_{\downarrow}$ and $L_{\downarrow}$. And vice versa, the lowest $L_{\uparrow}$, along with smaller $K_{\downarrow}$ and $L_{\downarrow}$, measured in winter. The highest monthly mean $L_{\uparrow}$ of $467 \mathrm{~W} \mathrm{~m}^{-2}$ occurred in July and the smallest $\left(275 \mathrm{~W} \mathrm{~m}^{-2}\right)$ again in January 2013. Surface materials vary little over short periods, beyond the small impacts presence of snow and wet surfaces, but over multi-year periods external (e.g. building) materials will change having some influence. The latter is not relevant to this study.

As the net all-wave radiation $\left(Q^{*}\right)$ is net balance of the four radiation budget components, it is affected by sun elevation angle, sky conditions, and surface characteristics. The variation of $Q^{*}$ is similar to that of the $K_{\downarrow}$, with daytime maxima of $Q^{*}$ being greater in summer and less in winter. Daily mean $Q^{*}$ values vary between $-20 \mathrm{~W} \mathrm{~m}^{-2}$ (winter) and $222 \mathrm{~W} \mathrm{~m}^{-2}$ (summer), with large scatter seen from May to 
September (Fig. 3e). Hence, the largest monthly mean $Q^{*}$ in summer, with the maximum value $(126 \mathrm{~W}$ rainfall. Notably, the 4th June's extremely low $K_{\downarrow}$ results in a daily mean $Q^{*}$ than is $<0 \mathrm{~W} \mathrm{~m}^{-2}$. With longer winter nights the monthly mean $Q^{*}$ is small or even negative. Notably, the minimum value during the observation period is in December 2012 when snow is present (i.e. increasing $K_{\uparrow}$ ) resulting in a monthly mean of only $-0.5 \mathrm{~W} \mathrm{~m}^{-2}$ (Fig. 3e).

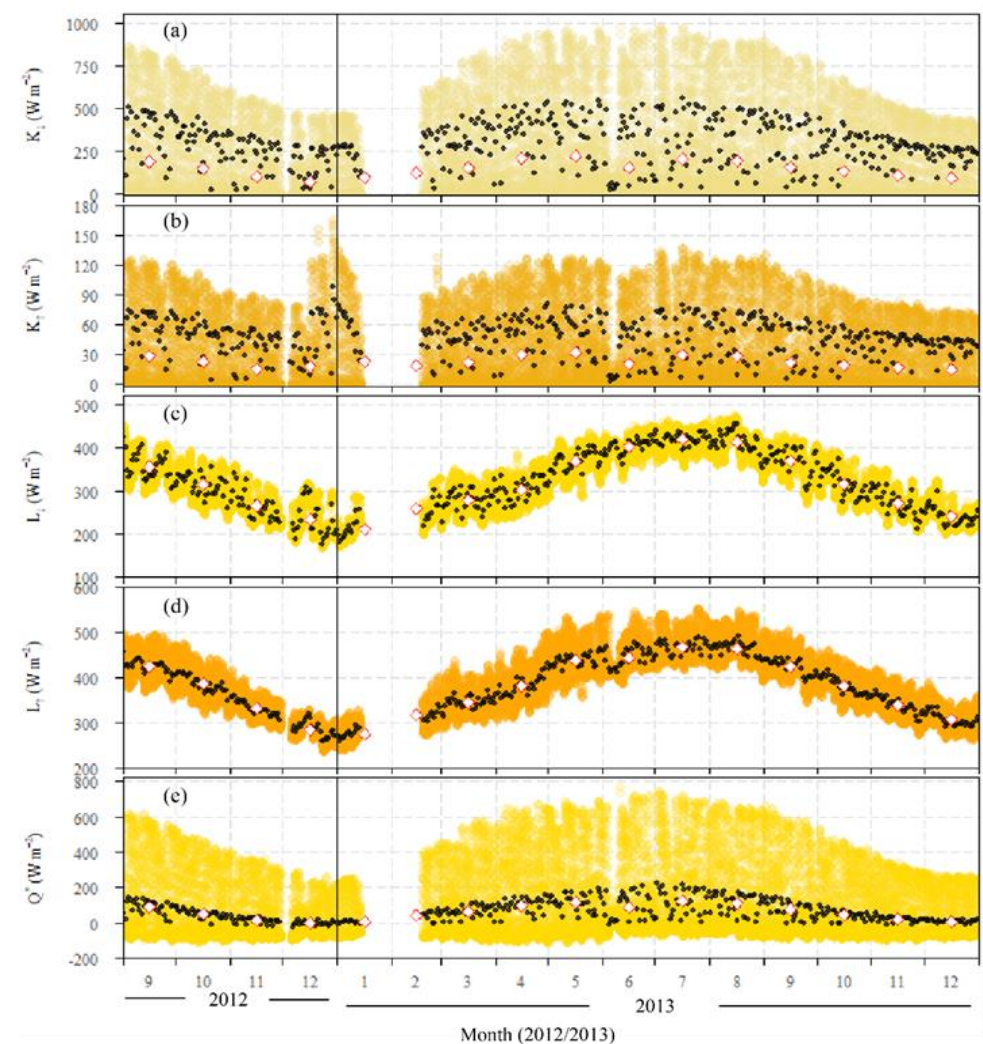

Figure 3: Observed $30 \mathrm{~min}$ (colour), daily (black) and monthly (white diamonds) means at Miyun (September 2012 to December 2013) of (a) incoming shortwave radiation $\left(K_{\downarrow}\right)$, (b) outgoing shortwave radiation $\left(K_{\uparrow}\right)$, (c) incoming longwave radiation $\left(L_{\downarrow}\right)$, (d) outgoing longwave radiation $\left(L_{\uparrow}\right)$, and (e) net all-wave radiation $\left(Q^{*}\right)$. Data gap in January and February 2013 due to instrument failure. For the daily fluxes they are daytime $\left(K_{\downarrow}>5 \mathrm{~W} \mathrm{~m}^{-2}\right)$ for the

shortwave fluxes but $24 \mathrm{~h}$ for the others.

\subsection{Anthropogenic heat $\left(Q_{F}\right)$ and storage heat $\left(\Delta Q_{S}\right)$ fluxes}

The median $Q_{F}$ vary between 5 and $39 \mathrm{~W} \mathrm{~m}^{-2}$ diurnally across all of the months (Fig. 4). The fluxes are larger in summer and winter associated with cooling and heating needs, respectively. The monthly mean 
$Q_{F}$ vary between 17 and $24 \mathrm{~W} \mathrm{~m}^{-2}$ (daily totals $=1.46-2.10 \mathrm{MJ} \mathrm{d}^{-1} \mathrm{~m}^{-2}$ ). These suburban values are larger

${ }^{2}$ in Montreal during winter (Bergeron and Strachan, 2012), and 6-10 $\mathrm{W} \mathrm{m}^{-2}$ in Swindon (Ward et al., 2013). However, these suburban Beijing values are much less than the Beijing city-centre $\left(\sim 130 \mathrm{~W} \mathrm{~m}^{-2}\right.$, Wang et al., 2020). Hence, the MY values appear to be reasonable.

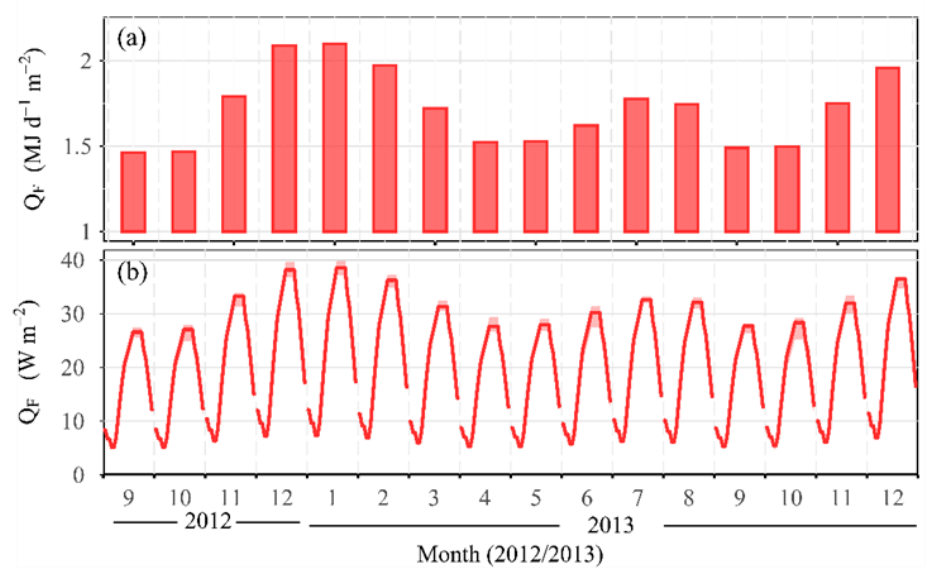

265 Figure 4: Monthly anthropogenic heat flux $\left(Q_{F}\right)$ at Miyun (September 2012 to December 2013) calculated as described in Section 2.2: (a) mean total for $24 \mathrm{~h}$, (b) median diurnal patterns with inter-quartile range (IQR) (shading).

The storage heat fluxes are determined using two methods (Sect. 2.6). Generally, storage heat flux is expected to have a net gain in summer and net loss in winter, giving almost zero net heat gain/release over the annual period (Grimmond et al., 1991). From this point of view, $\Delta Q_{S, \text { ohm }}$ has a credible annual variation in daily total values (Fig. 5a) but may be a little low in winter. Although the $\Delta Q_{s, o h m}$ underestimates more frequently during easterlies, given it is the prevailing wind direction there is no clear relation between underestimated $\Delta Q_{s, o h m}$ and wind direction or time of the day.

In autumn and winter (November - February) the differences in mean and median are negligible (< $0.5 \mathrm{~W} \mathrm{~m}^{-2}$ ) (Fig. 5). However, similar to residential Swindon results (Ward et al., 2013) $\Delta Q_{s_{\text {, }} h m}$ is smaller than $\Delta Q_{s \text {, res }}$ during the day but larger (more negative) at night (Fig. 5b). It is partly attributed to our $\Delta Q_{s_{\text {, }} \text { m }}$ coefficients not including all components of heat storage flux, such as biomass heat storage flux (Meyers and Hollinger, 2004; Oliphant et al., 2004). 
The site OHM coefficients (Equation B1) should vary with source area characteristics. The MY site coefficients vary with season and time of day (Fig. S2). With annual values for suburban Swindon (Ward et al. 2013, Fig. S2), we can compare results, the winter values at MY, have a larger both $a_{1}$ (slope of the relation between $\Delta Q_{S}$ and $Q^{*}$ ) and $a_{3}$ term (displacement of the $\Delta Q_{S}$ and $Q^{*}$ peaks), whereas $a_{2}$ is smaller (hysteresis; Grimmond et al., 1991; Oke and Meyn, 2009). These result in Swindon having a smaller diurnal range of $\Delta Q_{S_{,} \text {ohm }}$ than at MY (Fig. S3).

As MY site has larger wintertime $Q_{F}$ emissions, which direct impacts $\Delta Q_{S \text {, res }}$ we make a second estimate which omits $Q_{F}$ and assumes the turbulent heat fluxes are underestimated by $20 \%$ (Wilson et al., 2002; Foken et al., 2008) $\left(\Delta Q_{s_{\text {, res }-v 2}}=Q^{*}-1.2 *\left(Q_{H}+Q_{E}\right)\right)$. This gives a lower limit, with $\Delta Q_{s, \text { ohm }}$ smaller than $\Delta Q_{s_{\text {,res }-v 2}}$ in winter (Fig. S5). This indicates the winter $\Delta Q_{s, o h m}$ underestimates are related to OHM coefficients for the cropland wind directions, suggesting the wheat coefficients are poor (Fig. B2d). This is because smaller fluxes are obtained from using the soil heat flux $\left(Q_{G}\right)$ data. These relations with $Q^{*}$ do not account for the crop biomass. Long-term datasets covering seasonal changes and surface conditions, especially winter, can provide more OHM coefficients for use (Anandakumar 1999, Ward et al. 2013). $\Delta Q_{s, \text { res }}$ is used in the following analyses, but it is clearly biased to when data are available monthly daily total values are all positive throughout the year, even in winter (Fig. 5a).

In spring and summer, there is little differences in daytime values of $\Delta Q_{s_{\text {, ohm }}}$ and $\Delta Q_{s_{\text {,res }}}$ except for May 2013 (Fig. 5b). The May high $\Delta Q_{s_{\text {, } h m}}$ is the result of both fewer rain events and more radiative input (Sect. 2.3 and 3.1; Fig. 2b, 3a). Under such conditions, more energy goes into heating the surface. There is a sharp drop in $\Delta Q_{S, \text { ohm }}$ at night, mainly associated with a sudden decrease in soil surface temperature $(0 \mathrm{~m})$ (Fig. S4) that leads to the corresponding drop in $Q^{*}$ that impacts $\Delta Q_{s, o h m}$ (Appendix B). The rapid decrease in soil surface temperature is evident each month (around 18:00-19:00) with the transition from day to night (Fig. S4), and also with the valley wind to mountain wind (Fig. 1a, 2g-j). The differences in soil temperature at night are less on clear day than on rainy day. 

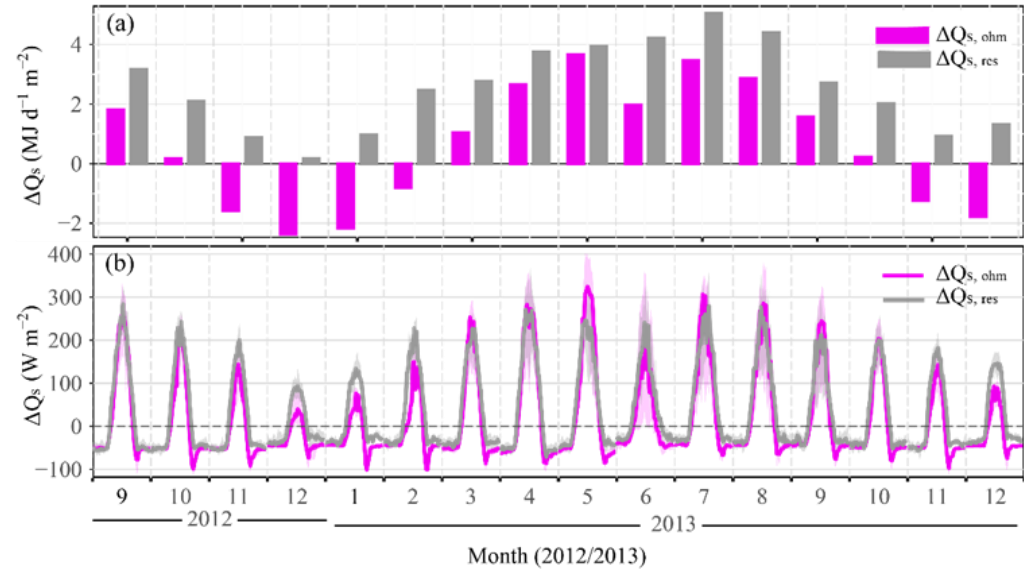

Figure 5: Miyun (September 2012 to December 2013) monthly storage heat flux $\left(\Delta Q_{S}\right)$ determined using two methods (colour, section 2.5): (a) $24 \mathrm{~h}$ mean, and (b) diurnal patterns median with inter-quartile range (shading).

\subsection{Monthly diurnal variation of directly observed fluxes}

Typically, $Q^{*}$, turbulent sensible $\left(Q_{H}\right)$ and latent heat fluxes $\left(Q_{E}\right)$ each have a unimodal distribution in the year, but with different seasonal peaks (Fig. 6). Monthly median diurnal maxima of $Q^{*}$ are higher from April to September, with the maximum value occurring in August reaching $600 \mathrm{~W} \mathrm{~m}^{-2}$. The daytime median maximum $Q^{*}\left(450 \mathrm{~W} \mathrm{~m}^{-2}\right)$ in June is slightly less than other months during this high-frequency rainfall period. The median diurnal $Q^{*}$ in December and January is obviously lower than other months, with a peak value of $180 \mathrm{~W} \mathrm{~m}^{-2}$ in December 2012 being the minimum value during the observation period. Nighttime $Q^{*}$ is around $-20 \mathrm{~W} \mathrm{~m}^{-2}$ during summer and mostly lies between -80 and $-60 \mathrm{~W} \mathrm{~m}^{-2}$ in other months. Overall, daytime values are greater than nighttime during the investigation period except for December $2012\left(-0.04 \mathrm{MJ} \mathrm{m}^{-2} \mathrm{~d}^{-1}\right)$, which results in monthly daily $Q^{*}$ being net positive values. These vary between $0.62 \mathrm{MJ} \mathrm{m}^{-2} \mathrm{~d}^{-1}$ and $10.88 \mathrm{MJ} \mathrm{m}^{-2} \mathrm{~d}^{-1}$ (Fig. 6a, b).

Sensible heat flux $Q_{H}$ is greatest in spring (March-May) and smallest in June-September 2013 (Fig. $6 \mathrm{c}, \mathrm{d})$. The daytime median peak values for these two periods are close to $200 \mathrm{~W} \mathrm{~m}^{-2}$ and $\sim 90 \mathrm{~W} \mathrm{~m}^{-2}$, respectively. In other months, daytime $Q_{H}$ maximum values tend to of be between $100-130 \mathrm{~W} \mathrm{~m}^{-2}$, but in February 2013 approach $170 \mathrm{~W} \mathrm{~m}^{-2}$. In previous suburban studies, daytime $Q_{H}$ values are lowest in winter when least solar radiation in the year occurs (e.g. Christen and Vogt, 2004; Goldbach and Kuttler, 2012; Ward et al., 2013; Hong et al., 2019). However at MY, the summer daytime $Q_{H}$ minima is 
attributed to the extensive irrigated cropland in the prevailing wind direction (Fig. 1c, d; 2d, h). This enhances available energy to support evaporation and leads to smaller $Q_{H}$ values (Dou et al., 2019). Nocturnal $Q_{H}$ is negative throughout the year, from a mean of $-10.5 \mathrm{~W} \mathrm{~m}^{-2}$ in December (2013) to -4.3 $\mathrm{W} \mathrm{m}^{-2}$ in July, which is similar to those observed at more open suburban sites (Loridan and Grimmond 2012, their Table 2; Oke et al., 2017, their Figure 6.25;). At MY, daily total $Q_{H}$ on a monthly basis are smallest in winter, $1.07 \mathrm{MJ} \mathrm{m}^{-2} \mathrm{~d}^{-1}$ in December 2013, and largest in spring (4.53 $\mathrm{MJ} \mathrm{m}^{-2} \mathrm{~d}^{-1}$, April 2013) (Fig. 6c). Although the daytime $Q_{H}$ maxima are smallest in summer, the absolute values at night are smaller than that in winter, thus the minimum daily total value occurs in winter.

The seasonal pattern of $Q_{E}$ is driven by available energy, water supply (including precipitation and irrigation), and phenological variations. Along with the largest $Q^{*}$ and rainfall, as well as strongest crop growth in summer, daytime $Q_{E}$ peaks in July, with the maximum reaching $248 \mathrm{~W} \mathrm{~m}^{-2}$ (Fig. 6f). In winter, $Q_{E}$ is lowest with median diurnal values $<40 \mathrm{~W} \mathrm{~m}^{-2}$. In December 2013, during the long dry spell, with no precipitation from 20 October 2013 (Fig. 2b) and no irrigation (as crops are dormant, typically last irrigation is before 15 November) the maximum value is only $10 \mathrm{~W} \mathrm{~m}^{-2}$. Previous suburban studies report summer and winter daytime $Q_{E}$ maxima within this range, but at the higher and lower end, respectively (e.g. Grimmond et al., 2002; Spronken-Smith, 2002; Christen and Vogt, 2004; Moriwaki and Kanda, 2004; Goldbach and Kuttler, 2012; Dou et al., 2019). Similar to other urban and suburban studies, throughout the day $Q_{E}$ is positive (Grimmond and Oke, 1995; Balogun et al., 2009; Ward et al., 2013;

340 Ao et al., 2016b). At night $Q_{E}$ is close to zero, being slightly larger during June-August, between 2-19 $\mathrm{W} \mathrm{m} \mathrm{m}^{-2}$ (mean 7-26 $\mathrm{W} \mathrm{m}^{-2}$ during 20:00-0:00).

Monthly totals of $Q_{E}$ are between 0.32 and $7.16 \mathrm{MJ} \mathrm{d}^{-1} \mathrm{~m}^{-2}$ (Fig. 6e) with water vapor surface to atmosphere transport strongest in summer and weakest in winter during both the day and night. These corresponding maximum and minimum monthly totals occur in two seasons (summer - July and winter 

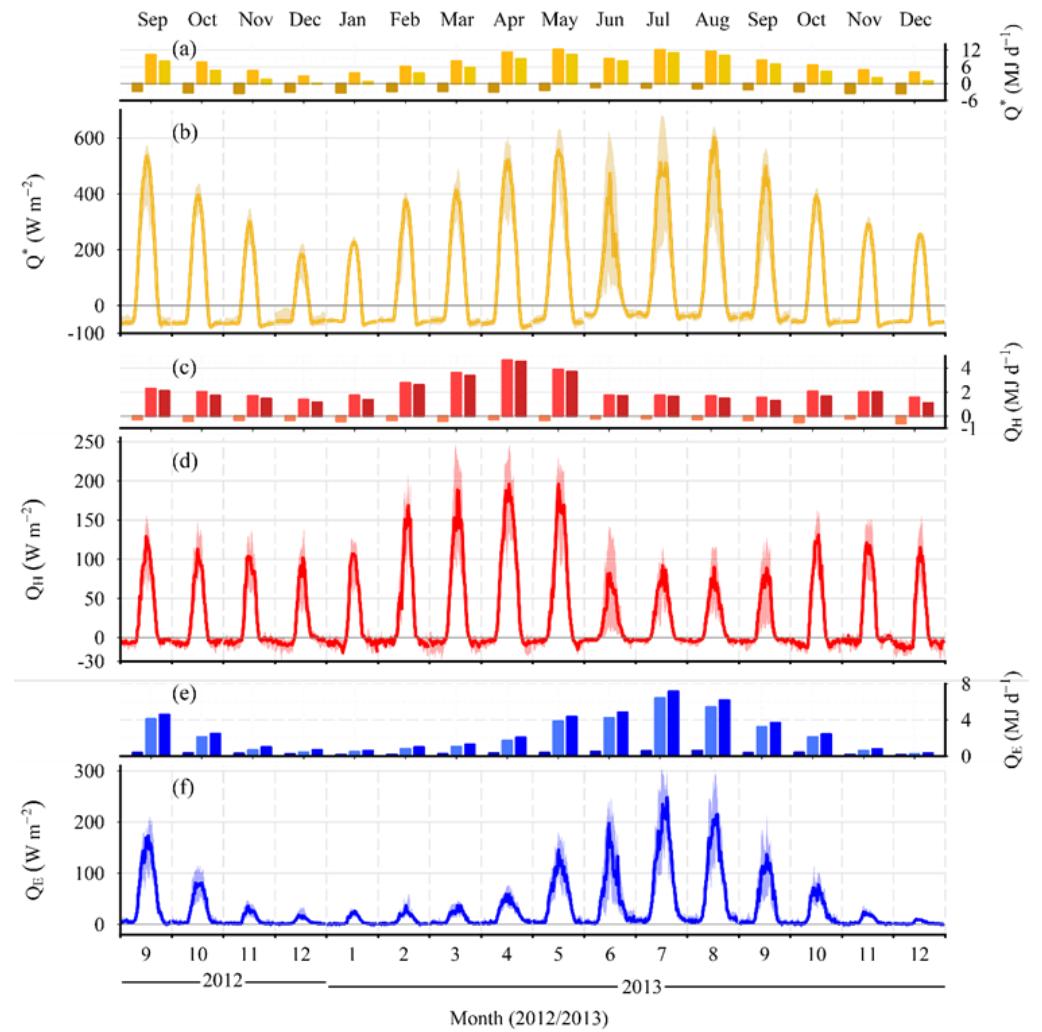

Figure 6: Miyun (09/2012-12/2013) monthly fluxes (a, c, e) total energy flux for night, day, and $24 \mathrm{~h}$ (left to right) and (b, d, f) diurnal median (line) and inter-quartile range (shading) for: (a, b) net all-wave radiation $Q^{*},(\mathrm{c}, \mathrm{d})$ sensible heat flux $Q_{H}$, and (e, f) latent heat flux $Q_{E}$.

\subsection{Surface energy balance partitioning}

To facilitate comparison of surface energy balance (SEB) partitioning between sites a series of average daily, and daytime $\left(K_{\downarrow}>5 \mathrm{~W} \mathrm{~m}^{-2}\right)$ flux ratios are analyzed. These include fluxes normalized by net allwave radiation $\left(Q^{*}\right)$ and the Bowen ratio $\left(\beta=Q_{H} / Q_{E}\right)$ (Fig. 7, 8; Table 2). The ratios are calculated at the 30 min time period allowing the distributions to be analyzed (Fig. 7) but also using monthly mean fluxes.

During the observation period, daytime $Q_{H}$ is $15-57 \%$ of $Q^{*}$ (Fig. 7). Unlike the absolute values (Sect. 3.3), $Q_{H} / Q^{*}$ is largest in winter and smallest in summer. Whereas $Q_{E} / Q^{*}$ has the opposite shape with annual peak in July (Fig. 7). It varies between 6-56\% during our study period.

At MY, from November to April (Fig. 7) $Q_{H}$ dominates the $Q^{*}$ ratio, whereas from June to September $Q_{E}$ dominates the $Q^{*}$ ratio. For May and October, they have a similar ratio with $Q^{*}$ (Fig. 7). 
This partitioning pattern is different from that observed in dense residential Tokyo where $Q_{H} / Q^{*}$ is always greater than $Q_{E} / Q^{*}$ throughout the year (Moriwaki and Kanda, 2004), also unlike the pattern reported in a suburban site Oberhausen where $Q_{E}$ is almost always dominant (Goldbach and Kuttler, 2012). These pattern differences could be partly attributed to the different vegetation cover, i.e. $\lambda_{V}=34 \%$ at MY, $21 \%$ at Tokyo, and $61 \%$ at Oberhausen.

The MY June-August daytime $Q_{E} / Q^{*}$ ratios between 0.49-0.56 (mean summer $=0.52$ ), are greater than most suburban sites, including those with more vegetation coverage than MY, such as Chicago $\left(Q_{E} / Q^{*}=0.38 ; \lambda_{V}=44 \% ;\right.$ Grimmond and Oke, 1995), and Basel $\left(Q_{E} / Q^{*}=0.30 ; \lambda_{V}=53 \% ;\right.$ Christen and Vogt, 2004). Therefore, MY June-August daytime $Q_{H} / Q^{*}$ ratios $(0.15-0.20$, summer mean $=0.16)$ are lower in comparison to previous studies (Grimmond and Oke, 2002; Balogun et al., 2009; Goldbach and Kuttler, 2012; Dou et al., 2019). Frequent rainfall and irrigation, prevailing winds from farmland, and rapid crop growth are all believed to enhance the latent heat flux, leading to higher $Q_{E} / Q^{*}$ and smaller Bowen ratio values (Sec. 3.5) and consistent with a previous study at the MY (Dou et al., 2019).

In winter, MY daytime $Q_{H}$ was $41-57 \%$ of $Q^{*}$, which is greater than most suburban sites and some urban sites, including sites with larger plan area of buildings $\left(\lambda_{b}\right)$, such as Tokyo $\left(Q_{H} / Q^{*}=35-40 \%\right.$; $\lambda_{b}=33 \%$; Moriwaki and Kanda, 2004), IAP Beijing $\left(Q_{H} / Q^{*}=28 \% ; \lambda_{b}=68.3 \%\right.$; Miao et al., 2012 $)$ and Mexico City $\left(Q_{H} / Q^{*}=38 \% ; \lambda_{b}=32 \%\right.$; Oke et al., 1999). However, the $Q_{E} / Q^{*}$ ratios $(0.08-0.18)$ are comparable to Tokyo $\left(Q_{E} / Q^{*}=0.07-0.11\right.$; Moriwaki and Kanda, 2004) and slightly larger than that of IAP Beijing $\left(Q_{E} / Q^{*}=0.07\right.$; Miao et al., 2012). This suggests the higher winter MY $Q_{H} / Q^{*}$ ratio could be attributed to its relatively lower heat absorbed and stored by buildings due to smaller $\lambda_{b}(18.9 \%)$. The $\Delta Q_{S}$ is a small proportion of in the $Q^{*}$ energy partitioning.

The partitioning between $Q_{H}$ and $Q_{E}$ has clear seasonal variations, with a similar tendency to that of $Q_{H} / Q^{*}$ (Fig. $8 \mathrm{cf}$. 7). The daytime $\beta$ varies between 0.26 and 7.40 through the year (Fig. 8). This range is much greater than many sites, such as 1.38-5.81 at Tokyo (Moriwaki and Kanda, 2004) and 0.36-1.23 at Oberhausen (Goldbach and Kuttler, 2012). The MY summer and winter (2012/2013) daytime mean $\beta$ (0.32 and 3.08/4.60) are at the lower and higher end of other suburban sites (Dou et al., 2019, their Figure 9c; Goldbach and Kuttler, 2012, their Table 1). Precipitation plays a significant role in the magnitude and amplitude of $\beta$ (Sect. 3.5). 

the daily $Q^{*}$ (i.e. $Q_{E}$ dominates) (Table 2 ). Similarly annual, daytime $\beta$ is 0.89 , and daily is 0.73 (i.e. $Q_{E}$

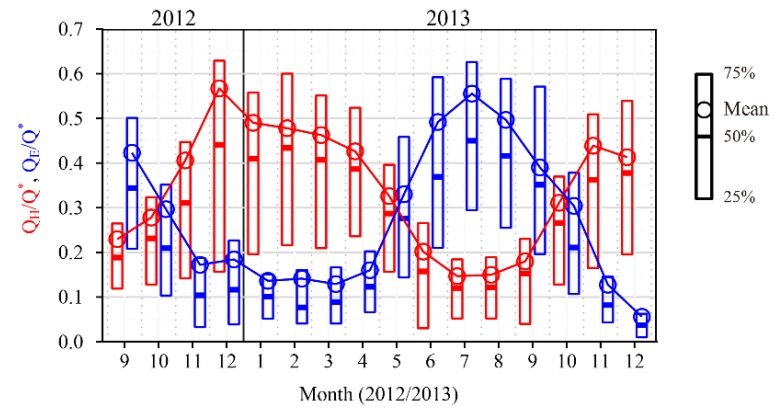

Figure 7: Monthly median, IQR and mean (30 min) of daytime $\left(K_{\downarrow}>5 \mathrm{~W} \mathrm{~m}^{-2}\right)$ sensible heat flux $Q_{H}$ and latent heat fluxes $Q_{E}$ normalized by net all-wave radiation $\left(Q^{*}\right)$ at MY (September 2012 to December 2013).

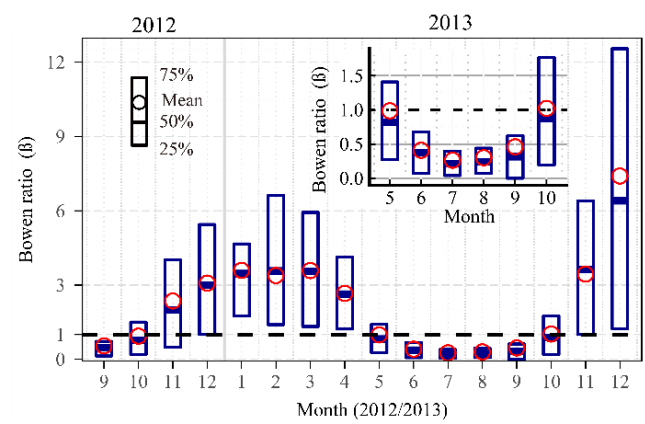

$395 \quad$ Figure 8: As Fig. 7 but Bowen ratio $(\beta)$ with inset from May to October 2013.

Table 1: Miyun site data availability by season for daytime $\left(K_{\downarrow}>5 \mathrm{~W} \mathrm{~m}^{-2}\right)$ and daily $(24 \mathrm{~h})$ period, with number of 30 min periods $(\mathrm{N})$ data and the percentage of time for each flux type: radiation fluxes, RAD (net all wave radiation, $Q^{*}$, incoming radiation $\left(Q_{\downarrow}=K_{\downarrow}+L_{\downarrow}\right)$ and are incoming and outgoing shortwave radiation $K_{\downarrow}, K_{\uparrow}$; incoming and outgoing longwave radiation $L_{\downarrow}$ and $L_{\uparrow}$, and albedo $=K_{\uparrow} / K_{\downarrow}, \Delta Q_{S \text {, ohm }}$ estimated using OHM model (Grimmond et al., 1991; Meyn and Oke, 2009)), turbulent sensible and latent heat fluxes $\left(Q_{H}, Q_{E}\right)$ and their ratios (radiative Rat; and Bowen ratio $\left(Q_{H} / Q_{E}\right)$; and storage heat flux calculated as $\Delta Q_{S \text {, res }}=\left(Q^{*}+Q_{F}\right)-\left(Q_{H}+Q_{E}\right)$. Note, anthropogenic heat flux. $Q_{F}$ calculated by LQF version (Gabey et al., 2019, Lindberg et al., 2018) of the LUCY model (Allen et al., 2011; Lindberg et al., 2013) is available for all hours.

\begin{tabular}{rccccccc}
\hline & 2012 & & 2013 & & & 2013 \\
Daytime & Autumn & Winter & Spring & Summer & Autumn & Winter & Year \\
\cline { 2 - 8 } & $6: 30-18: 00$ & $8: 00-16: 30$ & $6: 00-19: 00$ & $5: 30-19: 30$ & $6: 30-18: 00$ & $8: 00-17: 30$ & $6: 00-19: 00$ \\
\hline$N$ & 2275 & 558 & 2484 & 2668 & 2275 & 1800 & 9855 \\
$R A D$ & 98 & 84 & 100 & 99.9 & 100 & 61 & 90 \\
$Q_{H}$ & 91 & 82 & 97 & 91 & 71 & 54 & 78
\end{tabular}




\begin{tabular}{rccccccc}
$Q_{H}$ rat & 90 & 82 & 97 & 91 & 71 & 54 & 78 \\
$Q_{E}$ & 90 & 79 & 95 & 86 & 69 & 54 & 76 \\
$Q_{E}$ rat & 89 & 79 & 95 & 86 & 69 & 54 & 76 \\
Bowen & 89 & 79 & 94 & 84 & 69 & 53 & 75 \\
$\Delta Q_{S, \text { res }}$ & 88 & 79 & 94 & 84 & 69 & 53 & 75 \\
$\mathbf{2 4} \boldsymbol{h} / N$ & 4368 & 1488 & 4416 & 4416 & 4368 & 4320 & 17520 \\
$R A D$ & 99 & 85 & 100 & 99.9 & 100 & 61 & 90 \\
$Q_{H}$ & 89 & 81 & 96 & 89 & 66 & 54 & 76 \\
$Q_{H}$ rat & 89 & 81 & 96 & 89 & 66 & 54 & 76 \\
$Q_{E}$ & 88 & 78 & 94 & 85 & 65 & 54 & 75 \\
$Q_{E}$ rat & 87 & 78 & 94 & 85 & 65 & 54 & 75 \\
Bowen & 87 & 77 & 93 & 83 & 64 & 53 & 73 \\
$\Delta Q_{S \text {, res }}$ & 67 & 77 & 93 & 83 & 64 & 53 & 73 \\
\hline
\end{tabular}

405 Table 2: Seasonal and annual mean fluxes and ratios for the MY site. Table 1 gives symbols definitions and data availability.

\begin{tabular}{|c|c|c|c|c|c|c|c|c|c|c|c|c|c|c|}
\hline & \multicolumn{7}{|c|}{ Daytime $\left(K_{\downarrow}>5 \mathrm{~W} \mathrm{~m}^{-2}\right)$} & \multicolumn{7}{|c|}{ Daily } \\
\hline & 2012 & & 2013 & & & & 2013: & 2012 & & 2013 & & & & 2013: \\
\hline & Autumn & Winter & Spring & Summer & Autumn & Winter & Year & Autumn & Winter & Spring & Summer & Autumn & Winter & Year \\
\hline & $\mathrm{W} \mathrm{m} \mathrm{m}^{-2}$ & $\mathrm{~W} \mathrm{~m}^{-2}$ & $\mathrm{~W} \mathrm{~m}^{-2}$ & $\mathrm{~W} \mathrm{~m} \mathrm{~m}^{-2}$ & $\mathrm{~W} \mathrm{~m} \mathrm{~m}^{-2}$ & $\mathrm{~W} \mathrm{~m}^{-2}$ & $\mathrm{~W} \mathrm{~m}^{-2}$ & $\mathrm{MJ} \mathrm{d}^{-1}$ & $\mathrm{MJ} \mathrm{d}^{-1}$ & $\mathrm{MJ} \mathrm{d}^{-1}$ & $\mathrm{MJ} \mathrm{d}^{-1}$ & $\mathrm{MJ} \mathrm{d}^{-1}$ & $\mathrm{MJ} \mathrm{d}^{-1}$ & $\mathrm{MJ} \mathrm{d}^{-1}$ \\
\hline$K_{\downarrow}$ & 288.9 & 185.8 & 343.8 & 303.9 & 263.6 & 233.1 & 280.1 & 12.49 & 6.03 & 16.72 & 15.87 & 11.39 & 8.4 & 13.63 \\
\hline$K_{\uparrow}$ & 44.8 & 48.2 & 49.3 & 43.4 & 39 & 42.3 & 41.5 & 1.94 & 1.57 & 2.4 & 2.27 & 1.69 & 1.53 & 2.02 \\
\hline$L_{\downarrow}$ & 317.2 & 236 & 322.8 & 416.8 & 324.1 & 242.7 & 335.6 & 26.94 & 20.11 & 27.37 & 35.6 & 27.57 & 20.48 & 28.57 \\
\hline$L_{\uparrow}$ & 396.1 & 295 & 404.1 & 469.6 & 396.4 & 318.3 & 404.6 & 32.87 & 24.62 & 33.5 & 39.6 & 32.95 & 26.02 & 33.8 \\
\hline$Q_{\downarrow}$ & 606.1 & 421.8 & 666.6 & 720.7 & 587.7 & 475.8 & 615.7 & 39.42 & 26.14 & 44.09 & 51.46 & 38.96 & 28.88 & 42.19 \\
\hline$Q^{*}$ & 165.2 & 78.6 & 213.1 & 207.6 & 152.4 & 115.2 & 169.6 & 4.61 & -0.04 & 8.19 & 9.6 & 4.33 & 1.33 & 6.37 \\
\hline$\hat{Q}_{H}$ & 47.1 & 44.6 & 85.5 & 33.8 & 44.8 & 53 & 52.6 & 1.75 & 1.13 & 3.85 & 1.59 & 1.65 & 1.45 & 2.29 \\
\hline$Q_{E}$ & 56.4 & 14.5 & 48 & 108.5 & 45.7 & 11.5 & 58.9 & 2.7 & 0.65 & 2.57 & 6.09 & 2.22 & 0.52 & 3.13 \\
\hline$Q_{F}$ & 23.5 & 32.8 & 23.4 & 24.7 & 23.6 & 32.1 & 25.3 & 1.57 & 2.09 & 1.59 & 1.72 & 1.58 & 2.01 & 1.72 \\
\hline$\Delta Q_{S, \text { res }}$ & 95.6 & 55.5 & 106.3 & 108.5 & 83.8 & 84.3 & 92.8 & 2.07 & 0.17 & 3.48 & 4.55 & 1.89 & 1.45 & 3.08 \\
\hline Albedo & 0.16 & 0.26 & 0.14 & 0.14 & 0.15 & 0.18 & 0.15 & 0.16 & 0.26 & 0.14 & 0.14 & 0.15 & 0.18 & 0.15 \\
\hline$Q_{H} / Q_{E}$ & 0.83 & 3.08 & 1.78 & 0.31 & 0.98 & 4.6 & 0.89 & 0.65 & 1.72 & 1.5 & 0.26 & 0.74 & 2.81 & 0.73 \\
\hline$Q_{H} / Q^{*}$ & 0.29 & 0.57 & 0.4 & 0.16 & 0.29 & 0.46 & 0.31 & 0.38 & -28.26 & 0.47 & 0.17 & 0.38 & 1.09 & 0.36 \\
\hline$Q_{E} / Q^{*}$ & 0.34 & 0.18 & 0.23 & 0.52 & 0.3 & 0.1 & 0.35 & 0.59 & -16.42 & 0.31 & 0.64 & 0.51 & 1.08 & 0.49 \\
\hline$\Delta Q_{S_{\text {,res }}} / Q^{*}$ & 0.58 & 0.71 & 0.5 & 0.52 & 0.55 & 0.73 & 0.49 & 0.45 & -4.38 & 0.43 & 0.47 & 0.44 & 1.09 & 0.48 \\
\hline$Q_{H} / Q_{\downarrow}$ & 0.08 & 0.11 & 0.13 & 0.05 & 0.08 & 0.11 & 0.09 & 0.04 & 0.04 & 0.09 & 0.03 & 0.04 & 0.05 & 0.05 \\
\hline$Q_{E} / Q_{\downarrow}$ & 0.09 & 0.03 & 0.07 & 0.15 & 0.08 & 0.02 & 0.1 & 0.07 & 0.03 & 0.06 & 0.12 & 0.06 & 0.02 & 0.07 \\
\hline$\Delta Q_{S, \text { res }} / Q_{\downarrow}$ & 0.16 & 0.13 & 0.16 & 0.15 & 0.14 & 0.18 & 0.15 & 0.05 & 0.01 & 0.08 & 0.09 & 0.05 & 0.05 & 0.07 \\
\hline
\end{tabular}

\subsection{Factors influencing energy balance fluxes}

At MY, the impacts of precipitation on energy partitioning are obvious. As monthly rainfall from

September to December in 2012 and 2013 are higher and lower than the Normal (1981-2010) respectively,

of the same period in 2013. Notably with no precipitation in November and December 2013, the $\beta$ in

December 2013 reaches 7.57. This is 2.3 times greater than the December $2012(\beta=3.28)$. To our

knowledge, this large $\beta$ value is one of the highest observed in suburban area, but also the central part of cities (Miao et al., 2012, their Table 4 with vegetation cover of 2-29\%; Oke et al., 2017, their Figure 6.17 
415 with vegetation cover of 2-31\%) but still less than the values observed in central London (Kotthaus and Grimmond 2012) or Marseille (Grimmond et al. 2004).

Irrigation supplements precipitation and plays an important role in energy partitioning (Grimmond and Oke, 1986; Grimmond et al., 1996; Kokkonen et al., 2018). With only 3 days (26th, 27th and 28th May of 0.1, 0.4 and $0.2 \mathrm{~mm}$, respectively) having rain in May 2013 (Fig. 2b), soil moisture decreases dramatically in May unless replenished by irrigation (Fig. 9). However, the May $\beta$ clearly decreased because of the cropland irrigation (Fig. 10). The monthly mean $\beta$ of 0.50 , clearly indicates the importance of this additional source of water.

Crop growth and phenology are also important influences. Transpiration during crop growth releases a large amount of water into the atmosphere observed as $Q_{E}$ (e.g. Dou et al., 2019). The soil moisture in the irrigated cropland is higher than in the natural rainfed areas (Fig. 9). The gravimetric samples dates are critical relative to the timing of both irrigation and rainfall (e.g. 8 July 2013 cf. few days later) as the soil moisture values can inverse, as cropland utilizes stored soil water via transpiration and evaporation.

In addition to these factors, land use/cover also plays a critical role in the energy budget. At MY, normalizing by the incoming radiation $\left(Q_{\downarrow}=K_{\downarrow}+L_{\downarrow}\right)$ the $Q_{H} / Q_{\downarrow}$ and $\beta\left(Q_{E} / Q_{\downarrow}\right)$ are always more (less) when the wind is from directions with more buildings (cf. cropland-dominated) irrespective of season (Fig. 11). The temporal variations in $\beta$ after rainfall differ between these two direction types (Fig. 12). Water can drain relatively quickly after rain in the building-dominated direction because of the high proportion of impervious surface. Whereas, water can infiltrate into the soil (i.e. stored) so $\beta$ can remain near 1 for longer periods after rainfall (Fig. 12).

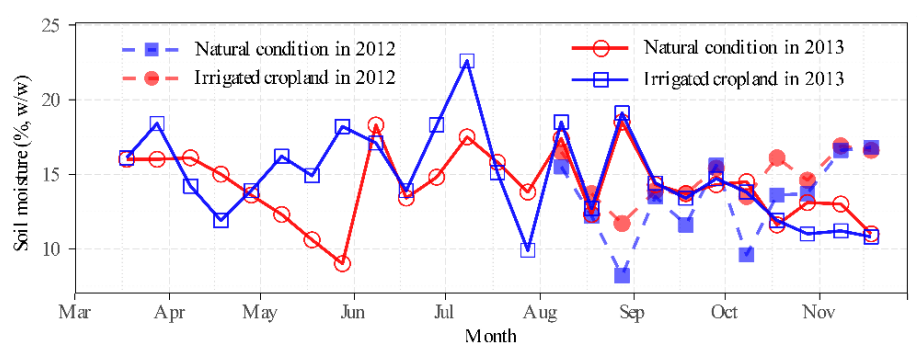


Figure 9: Gravimetric soil moisture (\%) at a depth of $0.1 \mathrm{~m}$ measured on the 8th, 18th and 28th of each month at the MY site from 8 August, 2012 to 18 November, 2013 under natural and irrigated cropland.

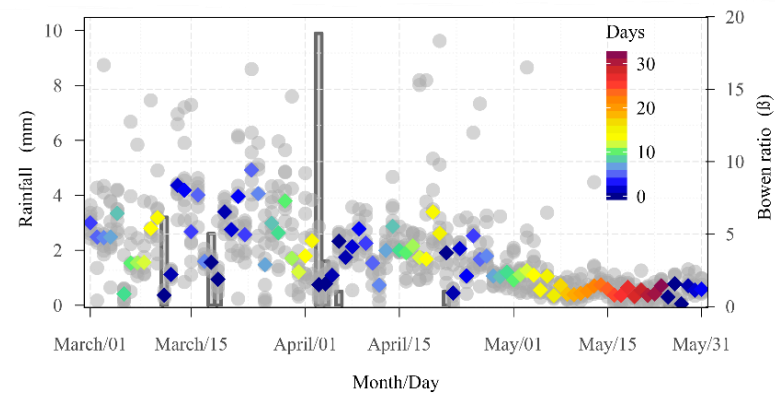

Figure 10: Daytime (circle) and median 30 min daytime (diamond) Bowen ratio by number of days since rainfall (colour) (right hand axis) and daily rainfall (bars, left-hand axis) for 1 March to 31 May 2013.
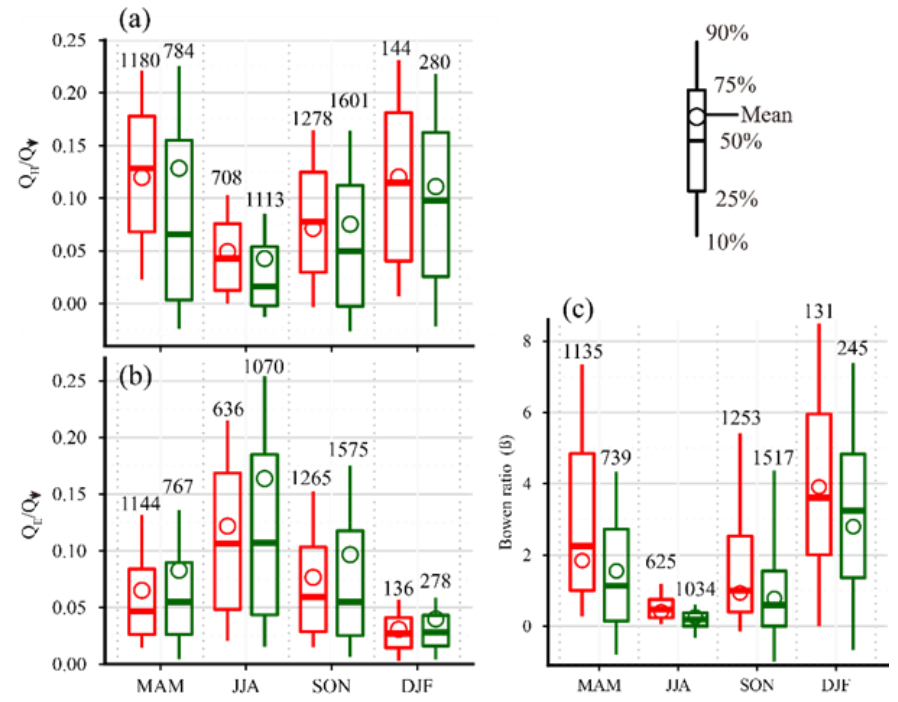

Figure 11: Median, IQR and mean flux ratio (30 min, number of periods indicated) by season when wind is from the building- (red) and farmland-dominant directions (dark green) (a) $Q_{H} / Q_{\downarrow}$ (b) $Q_{E} / Q_{\downarrow}$ and (c) $\beta$ (see Table 1 for definitions). 


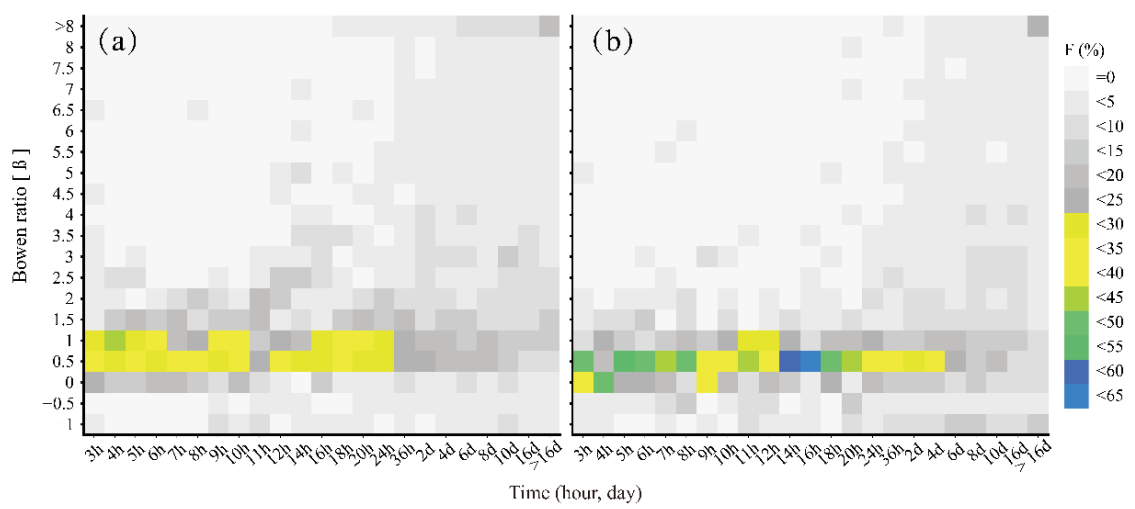

Figure 12: Frequency (F, \%) of Bowen ratio $\beta$ values by time since last rainfall for (a) building-dominant (210$\left.360^{\circ}\right)$ and (b) farmland-dominant $\left(30-150^{\circ}\right)$ directions.

In this analysis of surface energy flux measurements for a suburb (MY) of Beijing over 16 months we gain a better understanding of surface-atmosphere dynamics.

All five components of the radiation balance $\left(K_{\downarrow}, K_{\uparrow}, L_{\downarrow}, L_{\uparrow}, Q^{*}\right)$ have unimodal annual patterns, with higher values in summer (lower in winter) with the maximum monthly means in July (minima December / January).

At MY, daytime sensible heat flux $Q_{H}$ is greatest in spring. However, it is smallest in summer rather than winter, unlike previous suburban studies. This is a because of the prevailing wind direction has extensive cropland, irrigation, and frequent rainfall in summer. All of these factors are thought to play a role. Nocturnal $Q_{H}$ is negative throughout the year and smaller in winter, so the minimum daily total $Q_{H}$ still occurs in winter.

The latent heat flux $Q_{E}$ is positive throughout the day. The daytime maximum $Q_{E}$ is greatest in summer July (lowest in winter December) because of the influence of rainfall, irrigation, plant growth activity and available energy. Monthly median diurnal maxima of $Q_{E}$ vary from 10-248 $\mathrm{W} \mathrm{m}^{-2}$ during measurement period. These are close to both the smallest and largest values reported for suburban areas. 
Daytime $Q_{H} / Q^{*}$ is lower in summer (higher in winter). Across the year it varies from $15-57 \%$. $Q_{E} / Q^{*}$ has the opposite seasonal trends but similar annual range (6-56\%). Summer daytime means of $Q_{H} / Q^{*}(0.16)$ are lower and $Q_{E} / Q^{*}(0.52)$ higher than reported in most suburban areas. While in winter daytime $Q_{H} / Q^{*}(0.41-0.57)$ is greater than reported for most suburban sites but $Q_{E} / Q^{*}(0.08$ to 0.18$)$ is similar to other suburban sites. Thus the storage heat flux $\Delta Q_{S}$ at MY is a small fraction of $Q^{*}$ because of the low building fraction. At the annual time scale, daytime $Q_{H} / Q^{*}(31 \%)$ and $Q_{E} / Q^{*}(35 \%)$ are very similar but for the whole day the proportions are $36 \%$ and $49 \%$, respectively.

The large seasonal differences in precipitation and irrigation lead to a wide range in Bowen ratio $(\beta)$ values across the year (0.26-7.40). Daytime mean $\beta$ in summer (0.32) are lower than winter (4.60); and are on the lower and higher end of the range in the literature for suburban sites. The annual mean daytime $\beta$ is 0.89 and the daily value is 0.73 ; thus $Q_{E}$ dominates available energy.

The results confirm the combined importance of precipitation, irrigation, crop/vegetation growth and land cover as being key factors affecting energy partitioning in MY. These findings will help to enhance the understanding of the surface-atmosphere energy exchange over Chinese suburban areas, provide observational data for model verification and parameterization scheme improvement, and be a reference for formulating policies to mitigate the adverse effects of urban climate and climate change.

\section{Appendix A: Anthropogenic heat flux estimation}

LQF provides a method to calculate anthropogenic heat flux $Q_{F}$ (Gabey et al., 2019) based on population, vehicle, energy consumption and air temperature data. It estimates heat released from buildings $Q_{F, B}$, traffic $Q_{F, V}$, and human metabolism $Q_{F, M}$ (Allen et al., 2011; Lindberg et al. 2013). In this study, we determine appropriate temperature response coefficient for the MY area.

\section{A1 Temperature response coefficient}

In LQF, the mathematical expression of $Q_{F, B}$ is as follows:

$Q_{F, B}=\rho_{p o p} f_{b} E_{B, b}$ 
The coefficient, $f_{b}$, captures the air temperature response to of energy consumption. Given large differences in energy consumption between countries and between cities (e.g. Lindberg et al. 2013), it is emissions. Here $f_{b}$ varies with air temperature $T_{a}$ :

$f_{b}=\mathrm{C}+A_{c}\left(T_{a}-T_{b}\right), \quad T_{b}<T_{a}<T_{\max }$ $f_{b}=\mathrm{C}, \quad T_{a}=T_{b}$ $f_{b}=\mathrm{C}+A_{h}\left(T_{b}-T_{a}\right), \quad T_{\min }<T_{a}<T_{b}$

Several key parameters to determine $f_{b}$ are shown in Fig. A1. Here $T_{b}$ is the air temperature when the energy consumption is the lowest. If the air temperature is higher (lower) than $T_{b}$, more energy will be consumed due to cooling (heating). $A_{c}\left(A_{h}\right)$ is the building energy consumption thermal response slope for cooling when air temperature above (below) $T_{b}$, also known as a cooling (heating) coefficient. $C$ is the minimum energy consumption. $T_{\max }$ and $T_{\min }$ are threshold values for air temperature. When air temperature is beyond this range, energy consumption has reached saturation and no longer increases with air temperature changes.

A new set of temperature response parameters applicable to this region is obtained by using daily air temperature and electricity consumption data for the Miyun district in 2012-2013 (Table A1). The resulting parameters are given in Table A2. The energy consumption response to temperature changes is a "V"-shape curve in Miyun, rather than a "U"-shape as seen in Shanghai city (Ao et al., 2018). The cooling coefficient $A_{c}$ in MY is lower than that in Shanghai city $\left(0.04{ }^{\circ} \mathrm{C}^{-1}\right)$, which is attributed to relatively short period air conditioning in MY given the cooler summer nights caused by topography and continental monsoon climate. However, in winter with colder air temperatures and a longer heating period the heating coefficient $A_{h}$ for MY is higher than for Shanghai $\left(A_{h}=0.01^{\circ} \mathrm{C}^{-1}\right)$ (Ao et al., 2018). 
(a)

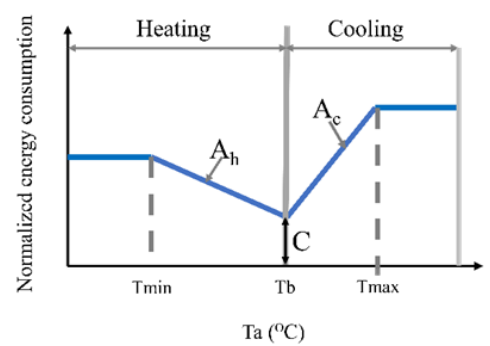

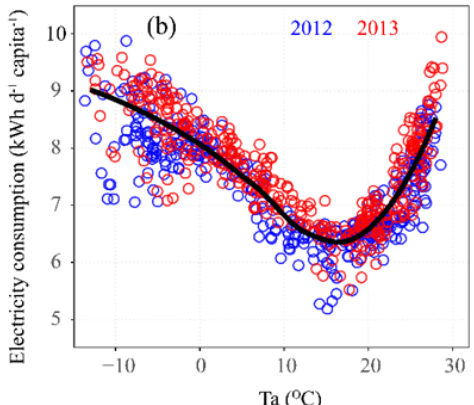

Ta $\left({ }^{\circ} \mathrm{C}\right)$

Figure A1: Energy consumption response to air temperature: (a) general response function (see text for definitions) and (b) data for Miyun District (Miyun District daily electricity consumption; kWh day ${ }^{-1}$ per capita; State Grid Beijing Electric Power Company, http://www.bj.sgcc.com.cn/) normalized by population (Beijing Miyun Statistical Yearbook, 2013; 2014) and MY daily mean air temperature (Ta) for 2012-2013 with general trend (black, loess curve).

Table A1: Energy consumption in Miyun (Beijing Miyun Statistical Yearbook, 2013; 2014) in ton coal equivalent (TCE) is converted to kilowatt hours assuming $1 \mathrm{TCE}=8141 \mathrm{kWh}$ (Kyle's Converter, 2017).

\begin{tabular}{lllcl}
\hline Year & $\begin{array}{l}\text { Energy } \\
\text { consumption } \\
\left(10^{4} \mathrm{TCE}\right)\end{array}$ & $\begin{array}{c}\text { Energy consumption } \\
(100 \text { million } \mathrm{kWh})\end{array}$ & $\begin{array}{c}\text { Electricity consumption } \\
(100 \text { million } \mathrm{kWh})\end{array}$ & $\begin{array}{l}\text { Electricity consumption } \\
/ \text { Energy consumption }\end{array}$ \\
\hline 2012 & 105.0 & 85.48 & 13.62 & 0.1593 \\
2013 & 109.3 & 88.98 & 14.34 & 0.1612 \\
\hline
\end{tabular}

Table A2. Parameters of energy consumption response to air temperature (equation A.2)

\begin{tabular}{lllllll}
\hline Site & $\begin{array}{l}\mathrm{T}_{\mathrm{b}} \\
\left({ }^{\circ} \mathrm{C}\right)\end{array}$ & $\begin{array}{l}\mathrm{A}_{\mathrm{h}} \\
\left({ }^{\circ} \mathrm{C}^{-1}\right)\end{array}$ & $\begin{array}{l}\mathrm{A}_{\mathrm{c}} \\
\left({ }^{\circ} \mathrm{C}^{-1}\right)\end{array}$ & $\begin{array}{l}\mathrm{C} \\
-\end{array}$ & $\begin{array}{l}\mathrm{T}_{\max } \\
\left({ }^{\circ} \mathrm{C}\right)\end{array}$ & $\begin{array}{l}\mathrm{T}_{\min } \\
\left({ }^{\circ} \mathrm{C}\right)\end{array}$ \\
\hline MY & 16 & 0.023 & 0.030 & 0.83 & 50 & -20 \\
\hline
\end{tabular}

\section{A2 Vehicle numbers}

525 In LQF, $Q_{F, V}$ is calculated as a function of vehicle numbers, traffic speed, and time (Ao et al., 2018). The average Beijing vehicle numbers per 1000 capita in 2012 and 2013 (Beijing Miyun Statistical Yearbook, $2013 ; 2014$ ) are: cars $=196.9$ and 201.7 , motorcycles $=11.7$ and 11.7 , and freight vehicles $=42.6$ and 43.7. For all vehicles it is assumed: an average vehicle speed $=48 \mathrm{~km} \mathrm{~h}^{-1}$ and a fuel of petrol to be used. Diurnal variation of vehicle numbers for weekdays, weekends, and holidays for Shanghai (Ao et al., 2018) are used as no such data are available for Miyun or Beijing. This will cause additional uncertainties. It is assumed that all the vehicle values may be slightly too large. 


\begin{abstract}
A3 Population density
The Miyun Meteorological Station is located within the "Gulou Street" administrative division of Miyun District. The population density of the "Gulou Street" area was 5657 and 5702 people km ${ }^{-2}$ in 2012 and 535 2013, respectively (Beijing Miyun Statistical Yearbook, 2013; 2014). This population density is much greater than in the Gridded Population of the World, version 4 (GPWv4; CIESIN, 2016) of about 1007 people $\mathrm{km}^{-2}$ around the study site. This is why Lindeberg et al. (2013) and Gabey et al. (2019) indicate the importance of updating data locally where ever possible.
\end{abstract}

\title{
Appendix B: Storage heat flux estimation using OHM
}

540 One of the two methods (Sect. 2.5) used in this study to determine the storage heat flux is the objective hysteresis model (OHM), which uses coefficients by land cover type $\left(a_{1, \mathrm{i}}-a_{3, \mathrm{i}}\right)$ with net all-wave radiation $Q^{*}$ (Grimmond et al., 1991; Meyn and Oke, 2009):

$\Delta Q_{s, o h m}=\sum_{i=1}^{n}\left\{a_{1 i} Q^{*}+a_{2 i}\left(\partial Q^{*} / \partial t\right)+a_{3 i}\right\} f_{i}$

where $t$ is time and, $f_{\mathrm{i}}$ is the area fraction covered by $i$ th land cover type. Given the differences in land cover around MY flux tower, the plan area fractions by $30^{\circ}$ wind sector footprint area are used to calculate $\Delta Q_{s, o h m}$ by direction (Fig. B1).

The coefficients used (Table B1) include values obtained from 30 min measured data of net radiation $Q^{*}$ and soil heat flux $Q_{G}$ in Weishan Farmland Experimental Station $\left(116^{\circ} 09^{\prime}\right.$ E, $\left.36^{\circ} 39^{\prime} \mathrm{N}\right)$. Weishan and MY have similar climate background, the same wheat/maize rotation pattern, and consistent growth cycle (Lei and Yang, 2010; Lei et al., 2018).

The Weishan station has a $10 \mathrm{~m}$ tower with a four-component radiometer (CNR1, Kipp \& Zonen, Netherlands) installed at $3.5 \mathrm{~m}$ agl and two soil heat flux plates (HFP01SC, Hukseflux, Netherlands) installed at a depth of $-0.03 \mathrm{~m}$. The instrument data are recorded at 10-min intervals using a CR10X data logger (Campbell Scientific, USA). The soil heat flux $Q_{G}$ data are the average of two measurement sites on the east and west of the tower.

For application convenience, the cropland coefficients are determined by season. A random, but arbitrary $70 \%$ of data are selected in each season to fit the coefficients. The remaining $30 \%$ is used to 
evaluate the simulation results. The results are good, but poorest in winter (Fig. B2). These values are used for the farmland (Table B1).

et al., 2008), with an average of summer and winter values used in spring and autumn. Other coefficients are used year round. For the Road/Impervious areas an average of literature values is used (Table B1).

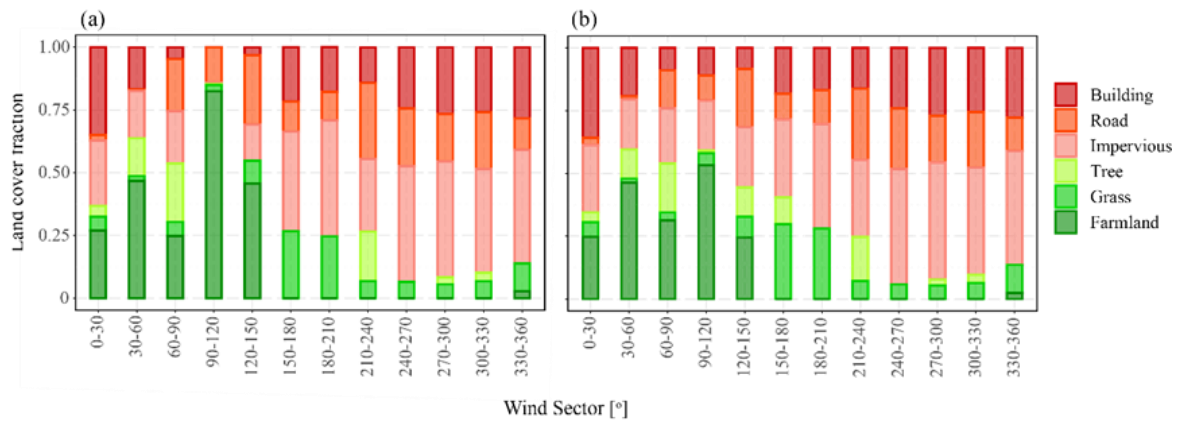

Figure B1: Land cover fraction for $30^{\circ}$ wind sectors, but varying footprint length (Section 2.4), around the MY flux tower for (a) day $\left(K_{\downarrow}>5 \mathrm{~W} \mathrm{~m}^{-2}\right)$ and (b) night.
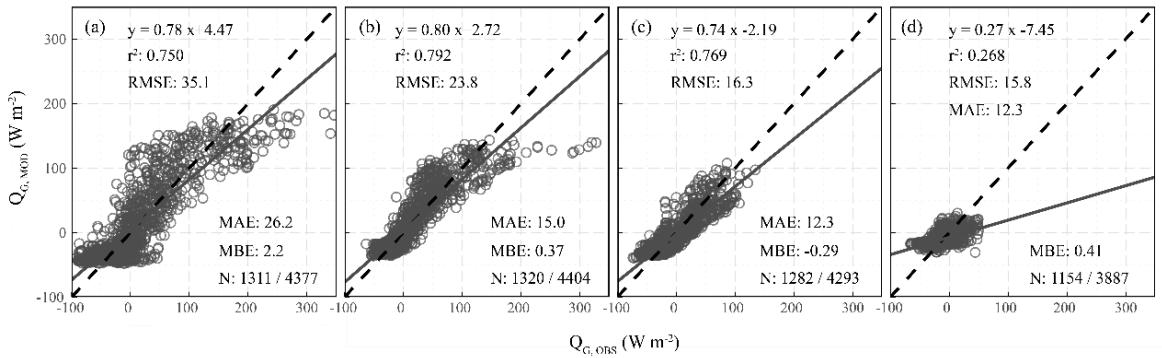

Figure B2: Weishan station modelled and observed soil heat flux, with statistical evaluation metrics (root mean square error (RMSE), coefficient of determination $\left(\mathrm{r}^{2}\right)$, mean absolute error (MAE) and mean bias error (MBE). N: evaluation data / total observations available) for (a) spring, (b) summer, (c) autumn and (d) winter.

Table B1: Coefficients used for the OHM (eqn B1) are from literature or derived in this study (*).

\begin{tabular}{|c|c|c|c|c|c|c|}
\hline \multirow{2}{*}{\multicolumn{3}{|c|}{ Surface cover }} & \multicolumn{3}{|c|}{ Coefficients } & \multirow[b]{2}{*}{ Source } \\
\hline & & & $a_{1}$ & $a_{2}(\mathrm{~h})$ & $\begin{array}{c}a_{3} \\
\left(W m^{-2}\right)\end{array}$ & \\
\hline \multirow[t]{5}{*}{ Vegetation } & & Tree & 0.11 & 0.11 & -12.3 & McCaughey (1985): Mixed forest \\
\hline & & Grass & 0.32 & 0.54 & -27.4 & Doll et al. (1985): Short grass \\
\hline & Wheat & at Spring & 0.29 & -0.19 & -20.7 & Weishan station, * \\
\hline & Wheat/Maize & Summer & 0.23 & -0.07 & -17.2 & $\begin{array}{l}\text { Weishan station, *: Wheat: June; } \\
\text { Maize: July and August }\end{array}$ \\
\hline & Maize/Wheat & Autumn & 0.21 & -0.14 & -17.6 & $\begin{array}{l}\text { Weishan station, *: Maize: September; } \\
\text { Wheat: October and November }\end{array}$ \\
\hline Building & & $\begin{array}{l}\text { Summer } \\
\text { Winter }\end{array}$ & $\begin{array}{l}0.83 \\
0.86\end{array}$ & $\begin{array}{l}0.52 \\
0.27\end{array}$ & $\begin{array}{l}-16.95 \\
-9.64\end{array}$ & $\begin{array}{l}\text { Wang et al (2008): Concrete roof } \\
\text { Wang }\end{array}$ \\
\hline
\end{tabular}




\begin{tabular}{|c|c|c|c|c|c|}
\hline \multirow{7}{*}{\multicolumn{2}{|c|}{$\begin{array}{ll}\text { Road/Impervious } & \text { Spring/Autumn }\end{array}$}} & 0.845 & 0.395 & -13.295 & Summer and winter mean \\
\hline & & 0.36 & 0.23 & -19.3 & Narita et al (1984): Asphalt \\
\hline & & 0.81 & 0.48 & -79.9 & Doll et al (1985): Concrete \\
\hline & & 0.85 & 0.32 & -28.5 & Asaeada and Ca (1993): Concrete \\
\hline & & 0.64 & 0.32 & -43.6 & Asaeada and Ca (1993): Asphalt \\
\hline & & 0.82 & 0.68 & -20.1 & Anandakumar (1999): Asphalt \\
\hline & & 0.696 & 0.406 & -38.28 & Average of road/impervious, * \\
\hline
\end{tabular}

\section{Data availability}

The observation data used in the study are available from the corresponding author with permission (Email: jxdou@ium.cn).

\section{Author contribution}

JD conducted the eddy covariance measurement, carried out the data analyses, and wrote the draft. SG supervised the scientific interpretation of the results and polished the writing. SM, BH, HL and ML provided key data sets and contributed to the anthropogenic heat flux estimation, and OHM coefficients fitting.

\section{Competing interests}

The authors declare that they have no conflicts of interest.

\section{Acknowledgments}

This research was supported by the Youth Beijing Scholars Program (Grant No. 2018-007), the National Natural Science Foundation of China (Grant No. 41505102), the Beijing Natural Science Foundation (Grant No. 8212026) and China Scholarship Council (CSC No. 201805330002). We offer special thanks to Weishan experiment station for providing observation data 585 of net radiation and soil heat flux in farmland used to fit OHM parameters in the paper. We thank all those who have supported the observation analyzed in this project. SG thanks the Newton Fund/Met Office CSSP-China project and ERC urbisphere (855005).

\section{References}

Allen, L., Lindberg, F., and Grimmond, C. S. B.: Global to city scale urban anthropogenic heat flux: Model and variability, Int. J. Climatol., 31, 1990-2005, doi:10.1002/joc.2210, 2011.

Anandakumar, K.: A study on the partition of net radiation into heat fluxes on a dry asphalt surface, Atmos. Environ., 33, 3911-3918, doi:10.1016/S1352-2310(99)00133-8, 1999. 
Ao, X. Y., Grimmond, C. S. B., Chang, Y. Y., Liu, D. W., Tang, Y. Q., Hu, P., Wang, Y. D., Zou, J., and Tan, J. G.: Heat, water and carbon exchanges in the tall megacity of Shanghai: challenges and results, Int. J. Climatol., 36, 4608-4624, doi:10.1002/joc.4657. 2016a.

Ao, X. Y., Grimmond, C. S. B., Liu, D. W., Han, Z. H., Hu, P., Wang, Y. D., Zhen, X. R., and Tan, J. G.: Radiation fluxes in a business district of Shanghai, China, J. Appl. Meteor. Climatol., 55, 24512468, doi:10.1175/JAMC-D-16-0082.1, 2016b.

Ao, X. Y., Grimmond, C. S. B., Ward, H. C., Gabey, A. M., Tan, J. G., Yang, X. Q., Liu, D. W., Zhi, X., Liu, H. Y., and Zhang, N.: Evaluation of the surface urban energy and water balance scheme (SUEWS) at a dense urban site in Shanghai: Sensitivity to anthropogenic heat and irrigation, J. Hydrometeorol., 19, 1983-2005, doi:10.1175/JHM-D-18-0057.1, 2018.

Asaeda, T., Ca, V. T.: The subsurface transport of heat and moisture and its act on the environment: a numerical model, Bound.-Layer Meteorol., 65, 159-178, doi:10.1007/BF00708822, 1993.

Baldocchi, D. D: Assessing the eddy covariance technique for evaluating carbon dioxide exchange rates of ecosystems: Past, present and future, Global Change Biol., 9, 479-492, doi:10.1046/j.13652486.2003.00629.x, 2003.

Balogun, A. A., Adegoke, J. O., Vezhapparambu, S., Mauder, M., McFadden, J., and Gallo, K.: Surface energy balance measurements above an exurban residential neighbourhood of Kansas City, Missouri, Bound.-Layer Meteorol., 133, 299-321, doi:10.1007/s10546-009-9421-3, 2009.

Beijing Miyun Statistical Yearbook: http://www.bjmy.gov.cn/art/2014/1/14/art_5733_284892.html, last access: 30 November 2021, 2013.

Beijing Miyun Statistical Yearbook: http://www.bjmy.gov.cn/art/2015/12/31/art_76_116972.html, last access: 30 November 2021, 2014.

615 Beijing Miyun Statistical Yearbook: http://www.bjmy.gov.cn/art/2020/11/19/art_76_339489.html, last access: 30 November 2021, 2020.

Bergeron, O. and Strachan, I. B.: Wintertime radiation and energy budget along an urbanization gradient in Montreal, Canada, Int. J. Climatol., 32, 137-152, doi:10.1002/joc.2246, 2012.

Center for International Earth Science Information Network, Gridded Population of the World, Version 4 (GPWv4): Population Count Grid. Palisades, NY: NASA Socioeconomic Data and Applications Center (SEDAC), Columbia University, http://sedac.ciesin.columbia.edu/data/set/gpw-v4population-density/metadata, 2016.

China Centre for Resources Satellite Data and Application: GF-2 (Gaofen-2) High-resolution Image, China Aerospace Science and Technology Corporation, http://218.247.138.119:7777/DSSPlatform/productSearch.html, 2016.

Christen, A., and Vogt, R.: Energy and radiation balance of a central European city, Int. J. Climatol., 24, 1395-1421, doi:10.1002/joc.1074, 2004.

Cleugh, H. A., and Oke, T. R.: Suburban-rural energy balance comparisons in summer for Vancouver, Bound.-Layer Meteorol., 36, 351-369, doi:10.1007/BF00118337, 1986.

630 Doll, D., Ching, J. K. S., and Kaneshiro, J.: Parameterization of subsurface heating for soil and concrete using net radiation data., Bound.-Layer Meteorol., 32, 351-372. doi:10.1007/BF00122000, 1985.

Dou, J. X., Grimmond, C. S. B., Cheng, Z. G., Miao, S. G., Feng, D. Y., and Liao, M. S.: Summertime surface energy balance fluxes at two Beijing sites, Int. J. Climatol., 39, 2793-2810, doi:10.1002/joc.5989, 2019.

635 Flerchinger, G. N., Xiao, W., Marks, D., Sauer, T. J., and Yu, Q.: Comparison of algorithms for incoming atmospheric longwave radiation, Water Resour. Res., 45, W03423. doi:10.1029/2008WR007394, 
Foken, T.: The energy balance closure problem: An overview, Ecol. Appl., 18, 1351-1367, doi:10.1890/06-0922.1, 2008.

Frey, C. M., Parlow, E., Vogt, R., Harhash, M., and Wahab, M. M. A.: Flux measurements in Cairo. Part 1: in situ measurements and their applicability for comparison with satellite data, Int. J. Climatol., 31, 218-231, doi:10.1002/joc.2140, 2011.

Gabey, A., Grimmond, C. S. B., and Capel-Timms, I.: Anthropogenic heat flux: advisable spatial resolutions when input data are scarce. Theor. Appl. Climatol., 135, 791-807, doi:10.1007/s00704018-2367-y, 2019.

Goldbach, A., and Kuttler, W.: Quantification of turbulent heat fluxes for adaptation strategies within urban planning, Int. J. Climatol., 33, 143-159, doi:10.1002/joc.3437, 2012.

Grimmond, C. S. B., Blackett, M., Best, M. J., Barlow, J., Baik, J. J., Belcher, S. E., Bohnenstengel, S. I., Calmet, I., Chen, F., Dandou, A., Fortuniak, K., Gouvea, M. L., Hamdi, R., Hendry, M., Kawai,

T., Kawamoto, Y., Kondo, H., Krayenhoff, E. S., Lee, S. H., Loridan, T., Martilli, A., Masson, V., Miao, S., Oleson, K., Pigeon, G., Porson, A., Ryu, Y. H., Salamanca, F., Shashua-Bar, L., Steeneveld, G. J., Tombrou, M., Voogt, J., Young, D., and Zhang, N.: The international urban energy balance models comparison project: First results from Phase 1, J. Appl. Meteor. Climatol., 49, 1268-1292, doi:10.1175/2010JAMC2354.1, 2010.

655 Grimmond, C. S. B., Souch, C., Hubble, M.: Influence of tree cover on summertime energy balance fluxes, San Gabriel Valley, Los Angeles, Climate Res., 6, 45-57, 1996.

Grimmond, C. S. B., and Oke, T. R.: Urban water balance II: Results from a suburb of Vancouver, BC, Water Resour. Res., 22, 1404-1412, doi:10.1029/WR022i010p01404, 1986.

Grimmond, C. S. B., Cleugh, H. A., and Oke, T. R.: An objective urban heat storage model and its comparison with other schemes, Atmos. Environ., 25B, 311-326, doi:10.1016/0957-1272(91)90003W, 1991.

Grimmond, C. S. B., and Oke, T. R.: Comparison of heat fluxes from summertime observations in the suburbs of four North American cities, J. Appl. Meteorol., 34, 873-889, doi:10.1175/1520-0450, 1995.

Grimmond, C. S. B., and Oke, T. R.: Aerodynamic properties of urban areas derived, from analysis of surface form, J. Appl. Meteorol., 38, 1262-1292, 1999a.

Grimmond, C. S. B., and Oke, T. R.: Heat storage in urban areas: Local-scale observations and evaluation of a simple model, J. Appl. Meteorol., 38, 922-940, 1999b.

Grimmond, C. S. B., and Oke, T. R.: Turbulent heat fluxes in urban areas: Observations and a local-scale urban meteorological parameterization scheme (LUMPS), J. Appl. Meteorol., 41, 792-810, 2002.

Grimmond, C. S. B., Salmond, J. A., Oke, T. R., Offerle, B., and Lemonsu, A.: Flux and turbulence measurements at a densely built-up site in Marseille: heat, mass (water and carbon dioxide), and momentum, J. Geophys. Res., 109, 241011-24120, doi:10.1029/2004JD004936, 2004.

Guo, W. D., Wang, X. Q., Sun, J. N., Ding, A. J., and Zou, J.: Comparison of land-atmosphere interaction at different surface types in the mid- to lower reaches of the Yangtze River valley, Atmos. Chem. Phys., 16, 9875-9890, doi:10.5194/acp-16-9875-2016, 2016.

Hong, J. W., Lee, S. D., Lee, K., and Hong, J.: Seasonal variations in the surface energy and $\mathrm{CO}_{2}$ flux over a high-rise, high-population, residential urban area in the East Asian monsoon region, Int. J. Climatol., 40, 4384-4407, doi:10.1002/joc.6463, 2019.

Järvi, L., Grimmond, C. S. B., and Christen, A.: The Surface Urban Energy and Water Balance Scheme (SUEWS): evaluation in Los Angeles and Vancouver, J. Hydrometeorol., 411, 219-237, 
doi:10.1016/j.jhydrol.2011.10.001, 2011.

Järvi, L., Grimmond, C. S. B., Taka, M., Nordbo, A., Setälä, H., and Strachan, I. B.: Development of the surface Urban Energy and Water Balance Scheme (SUEWS) for cold climate cities, Geosci. Model. Dev., 7, 1691-1711, doi:10.5194/gmd-7-1691-2014, 2014.

Järvi, L., Havu, M., Ward, H. C., Bellucco, V., McFadden, J. P., Toivonen, T., Heikinheimo, V., Kolari, P., Riikonen, A., Grimmond, C. S. B.: Spatial modeling of local-scale biogenic and anthropogenic carbon dioxide emissions in Helsinki, J. Geophys. Res-Atmos., 124, 8363-8384, doi:10.1029/2018JD029576, 2019.

Kanda, M., Inagaki, A., Miyamoto, T., Gryschka, M., and Raasch, S.: A new aerodynamic parametrization for real urban surfaces, Bound.-Layer Meteorol., 148, 357-377, doi:10.1007/s10546013-9818-x, 2013.

Karsisto, P., Fortelius, C., Demuzere, M., Grimmond, C. S. B., Oleson, K. W., Kouznetsov, R., Masson, V., and Järvi, L.: Seasonal surface urban energy balance and wintertime stability simulated using three land-surface models in the high-latitude city Helsinki, Q. J. Roy. Meteor. Soc., 142, 401-417, doi:10.1002/qj.2659, 2015.

Kent, C. W., Grimmond, C. S. B., Barlow, J., Gatey, D., Kotthaus, S., Lindberg, F., Halios, C. H.: Evaluation of urban local-scale aerodynamic parameters: implications for the vertical profile of wind and source areas, Bound.-Layer Meteorol., 164, 183-213, doi:10.1007/s10546-017-0248-z, 2017.

Kim, H., Hong, J. W., Lim, Y. J., Hong, J., Shin, S. S., and Kim, Y. J.: Evaluation of JULES land surface model based on in-situ data of NIMS flux sites, Atmosphere-Basel., 29, 355-365, doi:10.14191/Atmos.2019.29.4.355, 2019.

Kim, M. S., and Kwon, B. H.: Estimation of sensible heat flux and atmospheric boundary layer height using an unmanned aerial vehicle, Atmosphere, 10, 363. doi:10.3390/atmos10070363, 2019.

Kljun, N., Calanca, P., Rotach, M. W., and Schmid, H. P.: A simple parameterization for flux footprint predictions, Bound.-Layer Meteorol., 112, 503-523, doi:10.1023/B:BOUN.0000030653.71031.96, 2004.

Kokkonen, T. V., Grimmond, C. S. B., Christen, A., Oke, T. R., and Järvi, L.: Changes to the water balance over a century of urban development in two neighborhoods: Vancouver, Canada, Water Resour. Res., 54, 6625-6642, doi:10.1029/2017WR022445, 2018.

Kotthaus, S., and Grimmond, C. S. B.: Energy exchange in a dense urban environment- Part I: temporal variability of long-term observations in central London, Urban Clim., 10, 261-280, doi:10.1016/j.uclim.2013.10.002, 2014.

Kyle's Converter: Convert tons of coal equivalent to kilowatt-hours, Kyle's Converter, http://www.kylesconverter.com/energy,-work,-and-heat/tons-of-coal-equivalent-to-kilowatt--hours, last accessed: 1 December 2021.

Lei, H. M., and Yang, D. W.: Interannual and seasonal variability in evapotranspiration and energy partitioning over an irrigated cropland in the North China Plain, Agric. For. Meteorol., 150, 581-589, doi:10.1016/j.agrformet.2010.01.022, 2010.

Lei, H. M., Gong, T. T., Zhang, Y. C., and Yang, D. W.: Biological factors dominate the interannual variability of evapotranspiration in an irrigated cropland in the North China Plain. Agric. For. Meteorol., 250-251, 262-276, doi:10.1016/j.agrformet.2018.01.007, 2018.

Liang, X. D., Miao, S. G., Li, J., Bornstein, R., Zhang, X., Gao, Y., Chen, F., Cao, X., Cheng, Z., Clements, C., Dabberdt, W., Ding, A., Ding, D.,Dou, J. J., Dou, J. X., Grimmond, C. S. B., González-Cruz, J. E., He, J., Huang, M., Huang, X., Ju, S., Li, Q., Niyogi, D., Quan, J., Sun, J., Sun, J. Z., Yu, M., Zhang, 

convection and haze, Bull. Amer. Meteorol. Soc., 99, 1391-1413, doi:10.1175/BAMS-D-16-0178.1, 2018.

LI-COR, Inc: EddyPro software instruction manual, 7-75pp, https://www.licor.com/env/help/eddypro/topics_eddypro/EddyPro_Home.html, 2017.

Lindberg, F., Grimmond, C. S. B., Gabey, A., Huang, B., Kent, C. W., Sun, T., Theeuwes, N. E., Järvi, L., Ward, H. C., Capel-Timms, I., Chang, Y. Y., Jonsson, P., Krave, N., Liu, D. W., Meyer, D., Olofson, K. F. G., Tan, J. G., Wästberg, D., Xue, L., and Zhang, Z.: Urban multiscale environmental predictor (UMEP) - An integrated tool for city-based climate services, Environ. Modell. Softw., 99, 70-87, doi:10.1016/j.envsoft.2017.09.020, 2018.

Lindberg, F., Grimmond, C. S. B., Yogeswaran, N., Kotthaus, S., and Allen, L.: Impact of city changes and weather on anthropogenic heat flux in Europe 1995-2015, Urban Clim., 4, 1-15, doi:10.1016/j.uclim.2013.03.002, 2013.

Liu, H. Z., Feng, J. W., Järvi, L., and Vesala, T.: Four-year (2006-2009) eddy covariance measurements of CO2 flux over an urban area in Beijing, Atmos. Chem. Phys., 12, 7881-7892, doi:10.5194/acp-127881-2012, 2012.

Liu, X., Li, X. X., Harshan, S., Roth, M., and Velasco, E.: Evaluation of an urban canopy model in a tropical city: the role of tree evapotranspiration, Environ. Res. Lett., 12, 094008, doi:10.1088/17489326/aa7ee7, 2017.

Loridan, T., and Grimmond, C. S. B.: Characterization of energy flux partitioning in urban environments: links with surface seasonal properties, J. Appl. Meteor. Climatol., 51, 219-241, doi:10.1175/JAMCD-11-038.1, 2012.

McCaughey, J. H.: Energy balance storage terms in a mature mixed forest at Petawawa Ontario: A case study, Bound.-Layer Meteorol., 31, 89-101, doi:10.1007/BF00120036, 1985.

Mestayer, P. G., Durand, P., Augustin, P., Bastin, S., Bonnefond J. M., Bénech, B., et al.: The urban boundary-layer field campaign in Marseille (UBL/CLU-ESCOMPTE): Set-up and first results, Bound.-Layer Meteorol., 114, 315-365, doi:10.1007/s10546-004-9241-4, 2005.

Meyers, T. P., and Hollinger, S. E.: An assessment of storage terms in the surface energy balance of maize and soybean, Agric. For. Meteorol., 125, 105-115, doi:10.1016/j.agrformet.2004.03.001, 2004.

Meyn, S. K., and Oke, T. R.: Heat fluxes through roofs and their relevance to estimates of urban heat storage, Energ. Buildings, 41, 745-52, doi:10.1016/j.enbuild.2009.02.005, 2009.

Miao, S. G., Dou, J. X., Chen, F., Li, J., and Li, A. G.: Analysis of observations on the urban surface energy balance in Beijing, Sci. China Earth Sci., 55, 1881-1890, doi:10.1007/s11430-012-4411-6, 2012.

Michel, D., Philipona, R., Ruckstuhl, C., Vogt, R., and Vuilleumier, L.: Performance and uncertainty of CNR1 net radiometers during a one-year field comparison, J. Atmos. Ocean. Tech., 25, 442-451, doi:10.1175/2007JTECHA973.1, 2008.

Moncrieff, J. B., Massheder, J. M., de Bruin, H., Elbers, J., Friborg, T., Heusinkveld, B., Kabat, P., Scott, S., Soegaard, H., and Verhoef, A.: A system to measure surface fluxes of momentum, sensible heat, water vapour and carbon dioxide, J. Hydrol., 188-199, 589-611, doi:10.1016/S0022-1694(96)03194$0,1997$.

Moriwaki, R., and Kanda, M.: Seasonal and diurnal fluxes of radiation, heat, water vapor, and carbon dioxide over a suburban area, J. Appl. Meteor. Climatol., 43, 1700-1710, doi:10.1175/JAM2153.1, 2004. 
Narita, K., Sekine, T., and Tokuoka, T.: Thermal properties of urban surface materials: study on heat balance at asphalt pavement, Geog. Rev. Japan, Ser. A., 57, 639-651, doi:10.4157/grj1984a.57.9_639, 1984.

Offerle, B., Grimmond, C. S. B., Fortuniak, K., Kłysik, K., and Oke, T. R.: Temporal variations in heat fluxes over a central European city centre, Theor. Appl. Climatol., 84, 103-115, doi:10.1007/s00704005-0148-x, 2006a.

Offerle, B., Grimmond, C. S. B., Fortuniak, K., Pawlak, W.: Intraurban differences of surface energy fluxes in a central European city, J. Appl. Meteor. Climatol., 45, 125-136, doi:10.1175/JAM2319.1, 2006b.

Oke, T. R., Spronken-Smith, R. A., Jáuregui, E., Grimmond, C. S. B.: The energy balance of central Mexico City during the dry season, Atmos. Environ., 33, 3919-3930, doi:10.1016/S13522310(99)00134-X, 1999.

Oke, T. R., Mills, G., Christen, A., and Voogt JA.: Urban Climates, Cambridge: Cambridge University Press, 525 pp., doi:10.1017/9781139016476, 2017.

Oliphant, A. J., Grimmond, C. S. B., Zutter, H. N, Schmid, H. P., Su, H. B., Scott, S. L., Offerle, B., Randolph, J. C., and Ehman, J.: Heat storage and energy balance fluxes for a temperate deciduous forest, Agric. For. Meteorol., 126, 185-201, doi:10.1016/j.agrformet.2004.07.003, 2004.

Ren, Z. H., Zhang, Z. F., Sun, C., Liu, Y. M., Li, J., Ju, X. H., Zhao, Y. F., Li, Z. P., Zhang, W., Li, H. K., Zeng, X. J., Ren, X. W., Liu, Y., and Wang, H. J.: Development of three-step quality control system of real-time observation data from AWS in China, Meteorol. Monthly, 41, 1268-1277, doi:10.7519/j.issn.1000-0526.2015.10.010, 2015. (in Chinese)

Roberts, S. M., Oke, T. R., and Grimmond, C. S. B.: Comparison of four methods to estimate urban heat storage, J. Appl. Meteor. Climatol., 45, 1766-1781, doi:10.1175/JAM2432.1, 2006.

Rotach, M. W., Vogt, R., Bernhofer, C., Batchvarova, E., Christen, A., Clappier, A., Feddersen, B., Gryning, S. E., Martucci, G., Mayer, H., Mitev, V., Oke, T. R., Parlow, E., Richner, H., Roth, M., Roulet, Y. A., Ruffieux, D., Salmond, J. A., Schatzmann, M., and Voogt, J. A.: BUBBLE-an urban boundary layer meteorology project, Theor. Appl. Climatol., 81, 231-261, doi:10.1007/s00704-0040117-9, 2005.

Roth, M., Jansson, C., and Velasco, E.: Multi-year energy balance and carbon dioxide fluxes over a residential neighbourhood in a tropical city, Int. J. Climatol., 37, 2679-2698, doi:10.1002/joc.4873, 2017.

800 Spronken-Smith, R. A.: Comparison of summer- and winter-time suburban energy fluxes in Christchurch, New Zealand, Int. J. Climatol., 22, 979-992, doi:10.1002/joc.767, 2002.

Stewart, I. D., and Oke, T. R.: Local climate zones for urban temperature studies, Bull. Amer. Meteor. Soc., 93, 1879-1900, doi:10.1175/BAMS-D-11-00019.1, 2012.

Tomoya, A., and Masahito, U.: Surface energy exchange in a dense urban built-up area based on twoyear eddy covariance measurements in Sakai, Japan, Urban Clim., 19, 155-169, doi:10.1016/j.uclim.2017.01.005, 2017.

Vesala, T., Järvi, L., Launiainen, S., Sogachev, A., Rannik, Ü., Mammarella, I., Siivola, E., Keronen, P., Rinne, J., Riikonen, A., and Nikinmaa, E.: Surface-atmosphere interactions over complex urban terrain in Helsinki, Finland, Tellus. Ser. B. Chem. Phys. Meteor., 60, 188-199, doi:10.1111/j.16000889.2007.00312.x, 2008.

Wang, C. G., Sun, J. N., and Jiang, W. M.: Observation and analysis on thermodynamic characteristics of heat storage of urban roof, Acta Energiae Solaris Sinica, 6, 694-699, doi:10.3321/j.issn:0254- 
0096.2008.06.011, 2008.

Wang, L. L., Fan, S. H., Hu, F., Miao, S. G., Yang, A. Q., Li, Y. B., Liu, J. K., Liu, C. W., Chen, S. S., Ho, H. C., Duan, Z. X., Gao, Z. Q., and Yang, Y. J.: Vertical gradient variations in radiation budget and heat fluxes in the urban boundary layer: A comparison study between polluted and clean air episodes in Beijing during winter, J. Geophys. Res-Atmos., 125, e2020JD032478, doi:10.1029/2020JD032478, 2020.

Wang, L. L., Gao, Z. Q., Miao, S. G., Guo, X. F., Sun, T., Liu, M. F., and Li, D.: Contrasting characteristics of the surface energy balance between the urban and rural areas of Beijing, Adv. Atmos. Sci., 32, 505-514, doi:10.1007/s00376-014-3222-4, 2015.

Ward, H. C., Evans, J. G., and Grimmond, C. S. B.: Multi-season eddy covariance observations of energy, water and carbon fluxes over a suburban area in Swindon, UK, Atmos. Chem. Phys., 13, 4645-4666, doi:10.5194/acp-13-4645-2013, 2013.

Ward, H. C., Kotthaus, S., Järvi, and Grimmond, C. S. B.: Surface Urban Energy and Water Balance Scheme (SUEWS): Development and evaluation at two UK sites, Urban Clim., 18, 1-32, doi:10.1016/j.uclim.2016.05.001, 2016.

Webb, E., Pearman, G., and Leuning, R.: Correction of the flux measurements for density effects due to heat and water vapor transfer, Q. J. Roy. Meteor. Soc., 106, 85-100, doi:10.1002/qj.49710644707, 1980.

Wilson, K., Goldstein, A., Falge, E., Aubinet, M., Baldocchi, D., Berbigier, P., Bernhofer, C., Ceulemans, R., Dolman, H., Field, C., Grelle, A., Ibrom, A., Law, B. E., Kowalski, A., Meyers, T., Moncrieff, J., Monson, R., Oechel, W., Tenhunen, J., Valentini, R., and Verma, S.: Energy balance closure at FLUXNET sites, Agric. For. Meteorol., 113, 223-243, doi:10.1016/S0168-1923(02)00109-0, 2002. 